\title{
Summary of Sediment Resuspension Monitoring Activities, Old Tampa Bay and Hillsborough Bay, Florida, 1988-91
}

By Victor A. Levesque and David H. Schoellhamer

U.S. GEOLOGICAL SURVEY

Water-Resources Investigations Report 94-4081

Prepared in cooperation with the

SOUTHWEST FLORIDA WATER MANAGEMENT DISTRICT, HILLSBOROUGH COUNTY, PINELLAS COUNTY, the CITY OF ST. PETERSBURG, and the TAMPA PORT AUTHORITY

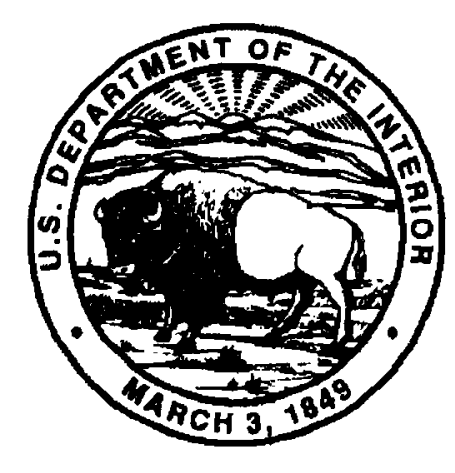




\title{
U.S. DEPARTMENT OF THE INTERIOR BRUCE BABBITT, Secretary
}

\author{
U.S. GEOLOGICAL SURVEY \\ Gordon P. Eaton, Director
}

Any use of trade, product, or firm names in this publication is for descriptive purposes only and does not imply endorsement by the U.S. Geological Survey

For additional information write to:

District Chief

U.S. Geological Survey

Suite 3015

227 North Bronough Street

Tallahassee, Florida 32301
Copies of this report can be purchased from:

U.S. Geological Survey

Earth Science Information Center

Open-File Reports Section

P.O. Box 25286, MS 517

Denver, CO 80225-0425 


\section{CONTENTS}

Abstract …

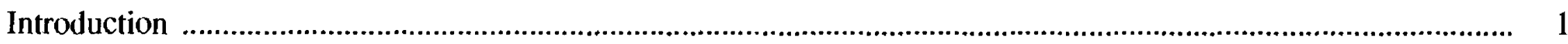

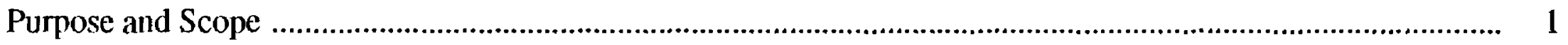

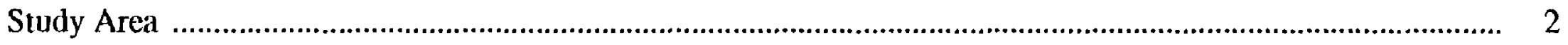

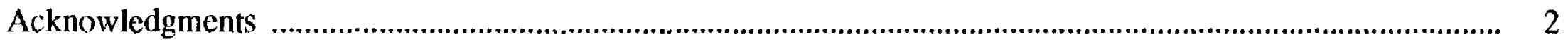

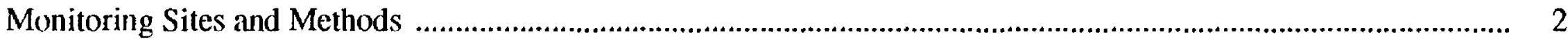

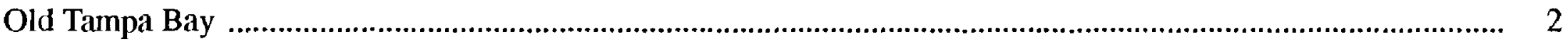

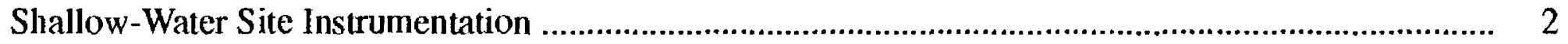

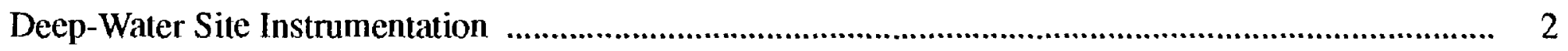

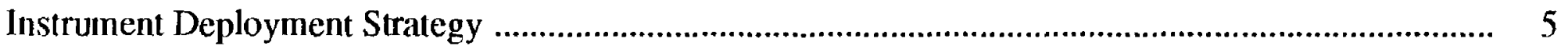

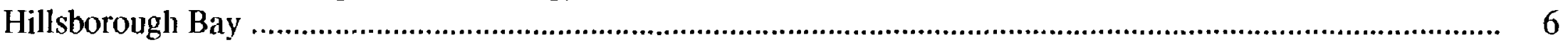

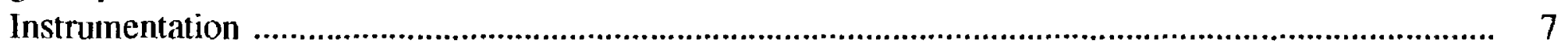

Instruments

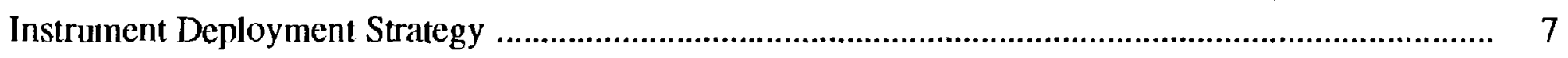

Description and Operation

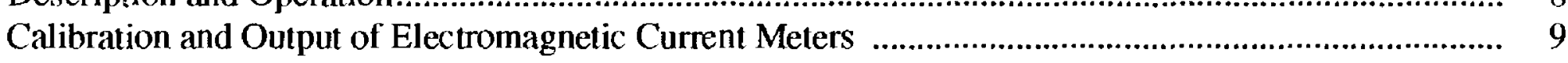

Calibration, Response Threshold, and Biological Interference of Optical Backscatterance Sensors ........ $\quad 9$

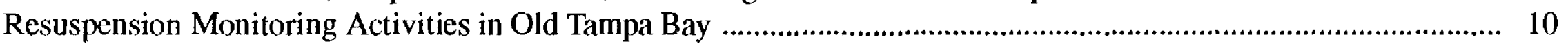

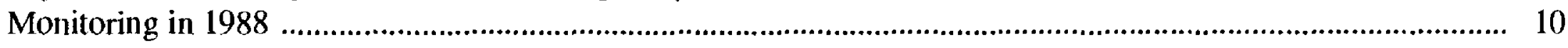

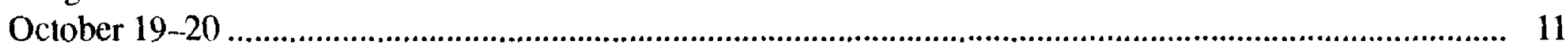

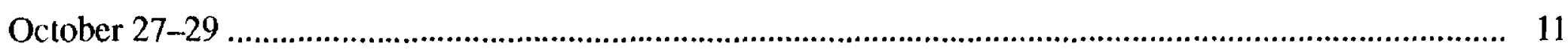

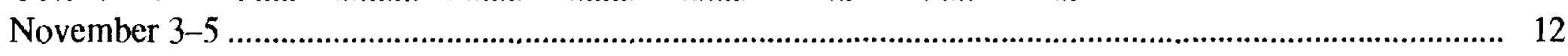

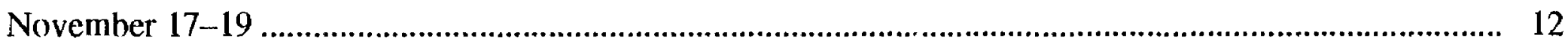

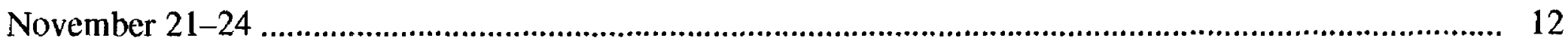

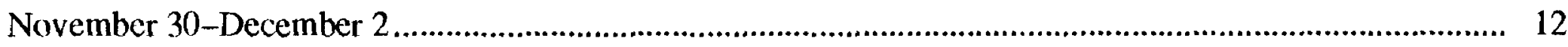

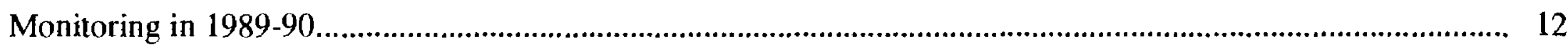

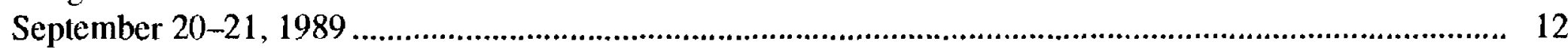

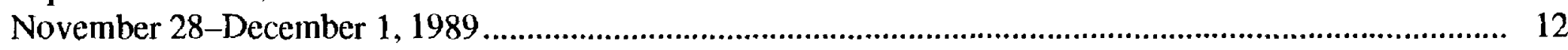

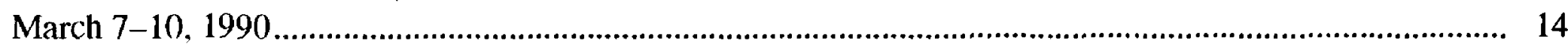

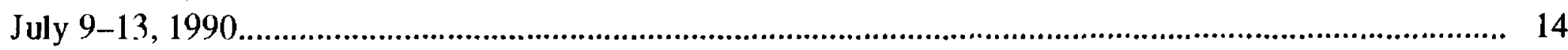

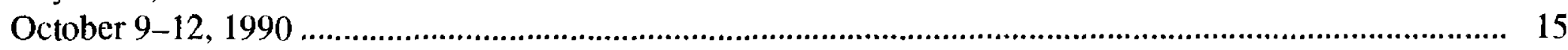

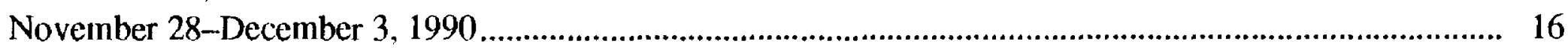

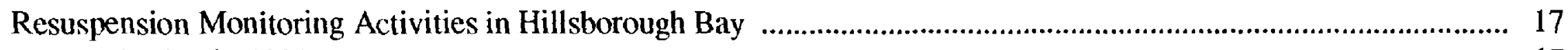

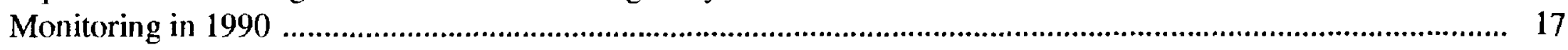

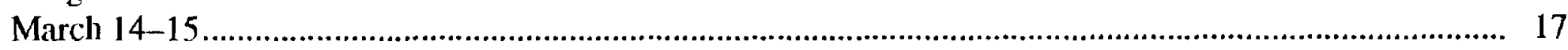

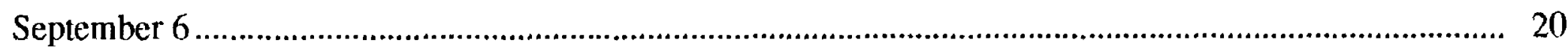

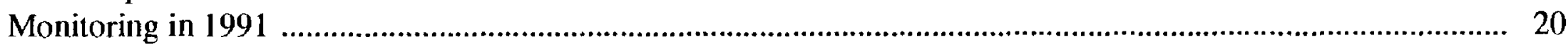

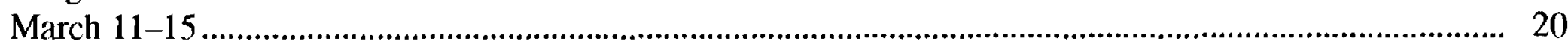

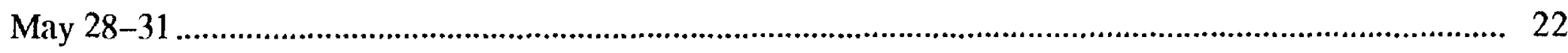

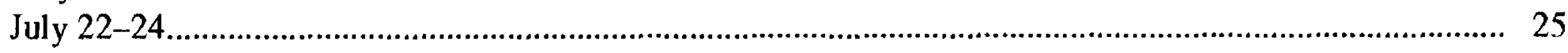

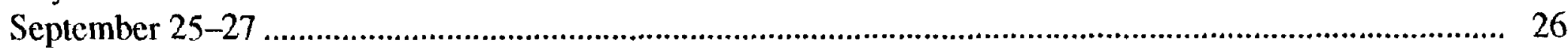

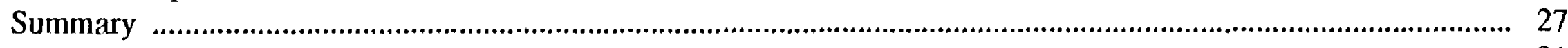

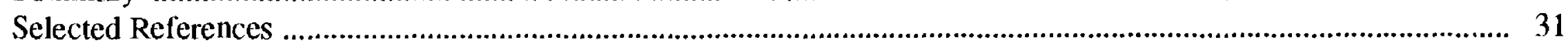

\section{ILLUSTRATIONS}

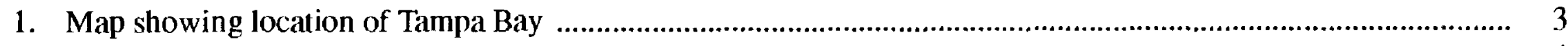

2. Map showing locations of monitoring sites in Old Tampa Bay ...................................................................

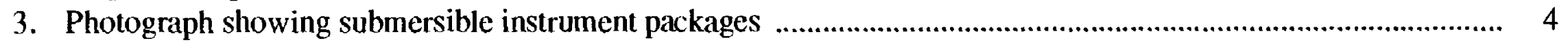


4. Photograph showing deep-water monitoring site platform in Old Tampa Bay.

5. Graph showing optical backscatterance sensor response to fouling and after cleaning .........................................

6. Map showing locations of monitoring sites in Hillsborough Bay

7-13. Graphs showing:

7. Example of an optical backscatterance calibration curve.

8. Hourly mean water depth, mean wind speed, and mean wind azimuth, November 28 -December 3, 1990 at the deep-water inonitoring site in Old Tampa Bay

9. Hourly mean north and east water velocity components, November 28 -December 3,1990 at the deepwater monitoring site in Old Tampa Bay

10. Hourly concentrations of suspended solids at 2.3 and 6.0 feet above the bed, November 28 -December 3 , 1990 at the deep-water monitoring site in Old Tampa Bay

11. Five-minute light attenuation coefficients, November 26-30,1990 at the deep-water monitoring site in Old Tampa Bay

12. Half-hourly mean water depth, north and east water velocity components, and concentrations of suspended solids, November 28-December 3,1990 at the shallow-water monitoring site in Old Tampa Bay 21

13. One-second water depths, north and east water velocity components, and concentrations of suspended solids, 0200 to 0204 hours, March 15, 1990 at the deep-water monitoring site B in Hillsborough Bay ........

14. Photograph showing shrimp trawler conducting fifth experimental trawl and sampling boat anchored at Hillsborough Bay deep-water monitoring site B, 1035 hours, May 28, 1991

15. Graph showing 1-minute averages of concentrations of suspended solids and 10-minute averages of the current speed measured 0900 to 1200 hours, May 28, 1991 at the deep-water monitoring site B in Hillsborough Bay ....

\section{TABLES}

1. Periods and summary of data collection in Old Tampa Bay for 1988

2. Operational deep-water monitoring site instrument elevations above the bed in Old Tampa Bay, October 19-20 and 27-29; November 3-5, 17-19, and 21-24; and November 30-December 2, 1988

3. Periods and summary of data collection in Old Tampa Bay for 1989 and 1990

4. Operational deep-water monitoring site instrument elevations above the bed in Old Tampa Bay, September 20-21, 1989

5. Operational deep-water monitoring site instrument elevations above the bed in Old Tampa Bay,

November 28-30, 1989

6. Operational deep-water monitoring site instrument elevations above the bed in Old Tampa Bay, March 7-10, 1990

7. Operational deep-water monitoring site instrument elevations above the bed in Old Tampa Bay, July $11-13,1990$

8. Operational deep-water monitoring site instrument elevations above the bed in Old Tampa Bay,

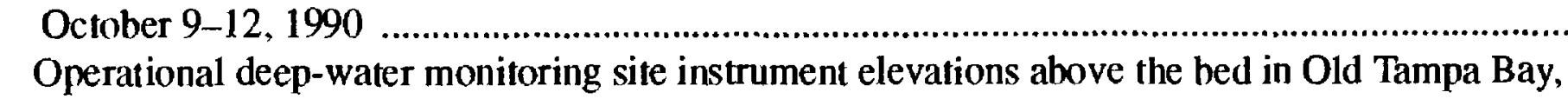

November 28-December 3, 1990

10. Water-quality data collected at the deep-water and shallow-water monitoring sites in Old Tampa Bay,

Deceınber 3, 1990

11. Periods and summary of data collection in Hillsborough Bay for 1990 and 1991

12. Vessel information and wake description for Hillsborough Bay instrumentation deployments in March and September 1990

13. Hillsborough Bay deep-water monitoring site B instrument elevations above the bed, March 11-15 and May 28-31, 1991

14. Vessel information and wake description for Hillsborough Bay instrumentation deployment in March 1991 ....... 24

15. Experimental trawls at Hillsborough Bay deep-water monitoring site $B$, May 28, 1991 ................................... 24

16. Vessel information and wake description for Hillsborough Bay instrumentation deployment in May 1991 .......... 26

17. Hillsborough Bay deep-water monitoring sites B and C instrument elevations above the bed, July $22-24$ and September 25-27, 1991

18. Vessel information and wake description for Hillsborough Bay instrumentation deployment in July 1991 ........... 28

19. Vessel information and wake description for Hillsborough Bay instrumentation deployment in September 1991 . 30 
CONVERSION FACTORS, ADDITIONAL ABBREVIATIONS, AND ACRONYMS

\begin{tabular}{lll}
\hline Multiply & By & To obtain \\
\hline inch (in.) & 25.40 & millimeter \\
foot $(\mathrm{ft})$ & 0.3048 & meter \\
foot per second $(\mathrm{ft} / \mathrm{s})$ & 0.3048 & meter per second \\
mile (mi) & 1.609 & kilometer \\
mile per hour $(\mathrm{mi} / \mathrm{h})$ & 1.609 & kilometer per hour \\
mile per hour & 0.869 & nautical mile per hour \\
& & (knots) \\
cubic foot $\left(\mathrm{ft}^{3}\right)$ & 0.02832 & cubic meter \\
ton, gross & 100 & cubic feet \\
\hline
\end{tabular}

\section{ADDITIONAL ABBREVIATIONS}

$\begin{array}{ll}\mathrm{Hz} & \text { Hertz } \\ \mathrm{L} & \text { liter } \\ \mu & \text { micron } \\ \mathrm{mg} / \mathrm{L} & \text { milligram per liter } \\ \mathrm{mL} & \text { milliliter }\end{array}$

\section{ACRONYMS}

$\begin{array}{ll}\text { OBS } & \text { optical backscatterance } \\ \text { PC } & \text { personal computer } \\ \text { PVC } & \text { polyvinyl chloride } \\ \text { USGS } & \text { U.S. Geological Survey }\end{array}$




\title{
Summary of Sediment Resuspension Monitoring Activities, Old Tampa Bay and Hillsborough Bay, Florida, 1988-91
}

\author{
By Victor A. Levesque and David H. Schoellhamer
}

\section{Abstract}

Sediment resuspension was studied in Old Tampa Bay, the northwestern subembayment of Tampa Bay, and in Hillsborough Bay, the northeastern subembayment of Tampa Bay located along the coast of west-central Florida. Suspended sediments in the water column can affect the amount of light that reaches seagrass meadows. Seagrass meadows are important ecosystems that provide habitat for many marine animals. Understanding the mechanisms that resuspend bottom sediments are a part of understanding these important habitats. Electromagnetic current meters, optical backscatterance sensors, and water samples were used to collect sediment resuspension data at the study sites using several instrument deployment strategies. This report describes the sediment resuspension monitoring data-collection methods and activities and summarizes the results of sediment resuspension data intermittently collected from October 1988 to December 1990 in Old Tampa Bay and from March 1990 to September 1991 in Hillsborough Bay.

\section{INTRODUCTION}

The resuspension of bottom sediments is one source for suspended materials in estuarine waters and these suspended materials are one cause of light attenuation. When bottom sediments are resuspended by waves or water currents and transported into the water column, the suspended sediments can alter the amount and quality of available light in the water column. Seagrass meadows are an important estuarine habitat that depend on light for their viability, and the existence of seagrass meadows in Tampa Bay is recognized as a necessity for the viability of the estuarine ecosystem. To obtain information and data that can be used to analyze and improve the understanding of the sediment resuspension mechanisms, the U.S. Geological Survey, in cooperation with the Southwest Florida Water Management District, Hillsborough County, Pinellas County, the City of St. Petersburg, and the Tampa Port Authority, has studied those mechanisms in Old Tampa Bay and Hillsborough Bay, two subembayments of Tampa Bay, Florida.

Water velocities and water constituents vary spatially and temporally in estuarine systems, and this variability required the selection of representative study sites. A representative collection network was used to monitor a part of Tampa Bay, and the data that were collected should be used with caution when referring to the entire estuary because of the spatial variability encountered in any large natural system.

\section{Purpose and Scope}

This report describes in detail the sediment resuspension monitoring activities and summarizes the results of sediment resuspension data intermittently collected by the USGS in Old Tampa Bay from October 1988 to December 1990 and in Hillsborough Bay from March 1990 to September 1991. Sediment resuspension was monitored at two sites in Old Tampa Bay and three sites in Hillsborough Bay using electronic sensors and water-sample collection and analyses. Examples of typical data are presented in this report; complete sets of data collected by the instruments deployed at each site are available from the files of the USGS in Tampa, Florida. 


\section{Study Area}

Old Tampa Bay is the northwestern subembayment of Tampa Bay, and Hillsborough Bay is the northeastern subembayment of Tampa Bay, that is located along the coast of west-central Florida (fig. 1). Two sites were used for sediment resuspension monitoring in Old Tampa Bay and three sites were used in Hillsborough Bay. Tampa Bay is classified as a shallow estuary with an average depth of about $12 \mathrm{ft}$ and has an average tidal range of $3 \mathrm{ft}$. The subtropical weather in the Tampa Bay area includes almost daily thunderstorms during the summer, the occasional possibility of tropical stonns from summer through fall, and occasional storms from cold fronts beginning in the fall and continuing through early spring.

\section{Acknowledgments}

The authors would like to thank those that provided assistance during this study. Vessel information for Hillsborough Bay was provided by the Tampa Port Authority and Tampa Bay Pilots Association. Mr. Robert Richards of Seabreeze Seafood provided the trawler and crew for the May 1991 Hillsborough Bay trawler experiment.

\section{MONITORING SITES AND METHODS}

Sediment resuspension could not be monitored simultaneously throughout Old Tampa Bay or Hillsborough Bay; therefore, representative sites for monitoring sediment resuspension in both bays were selected in 1988 (Schoellhamer, 1992). The size classification of the bottom sediments in Old Tampa Bay and Hillsborough Bay were determined with bottom grab samples and acoustic fathometry. The bottom sediment data were used to locate resuspension monitoring sites in large representative areas of nearly homogeneous bed sediments. After the monitoring sites had been selected, electronic instruments were deployed at the sites to collect water velocity, optical backscatterance, and water depth data.

\section{Old Tampa Bay}

Old Tampa Bay bottom sediments are generally fine sands in shallow water (less than $6 \mathrm{ft}$ ) near the shoreline and are generally silty, very fine sands in deeper waters (about $12 \mathrm{ft}$ ). A shallow-water monitoring site (fig. 2, average depth about $4 \mathrm{ft}$ ) was selected in an area of sandy botton material on the estuarine shelf at lat. $27^{\circ} 55^{\prime} 30^{\prime \prime} \mathrm{N}$ and long. $082^{\circ} 38^{\prime} 33^{\prime \prime} \mathrm{W}$. Fine sediments comprise 2 percent of the botton sediments at this site. A deep-water monitoring site (fig. 2, average depth about $12 \mathrm{ft}$ ) was located in the approximate center of a large area of silty-fine sand at lat. $27^{\circ} 57^{\prime} 01^{\prime \prime} \mathrm{N}$ and long. $082^{\circ} 37^{\prime} 55^{\prime \prime} \mathrm{W}$. Fine sediments comprise 16 percent of the bottom sediments at this site.

\section{Shallow-Water Site Instrumentation}

A submersible instrument package (fig. 3) was initially deployed at the Old Tampa Bay shallowwater monitoring site in November 1989. The shallow-water submersible instrument package consisted of a 6-ft-long, 6-in.-diameter schedule 40 polyvinyl chloride (PVC) pipe with one end sealed with a conventional schedule 40 PVC endcap glued in place. The other end of the PVC pipe was sealed with a specially modified schedule 40 PVC endcap that allowed access to the electronics inside the pipe, allowed sensor cables to be routed inside the pipe, and provided a water-tight seal. Instrument sensors, consisting of one biaxial electromagnetic current meter, an optical backscatterance (OBS) suspended-solids sensor, and a pressure transducer were mounted above a 1-ft-square, stainless-steel base plate. The biaxial electromagnetic current meter was mounted approximately $1 \mathrm{ft}$ above the base plate, the OBS sensor was fastened about $0.5 \mathrm{ft}$ below the current meter, and a strain-gage pressure transducer was attached to the base plate. Data acquisition, data storage, and sensor timing were controlled by an electronic data logger. Power was supplied by four 12-volt DC, 8-amperehour gel-cell batteries.

\section{Deep-Water Site Instrumentation}

An above water platform was constructed at the Old Tampa Bay deep-water monitoring site in June 1988. The platform consists of three vertical pilings supporting a triangular, galvanized, expanded-steel deck approximately $7 \mathrm{ft}$ (average) above the watcr surface (fig. 4) (Schoellhamer, 1990). Water column instrument sensors were mounted on movable horizontal aluminum arms that extended perpendicular to a vertical 20-ft-long, 4-in.diameter aluminum pipe that was fixed to the center of the steel deck. The entire pipe structure resembled an inverted tree and is referred to as the instrument tree. 


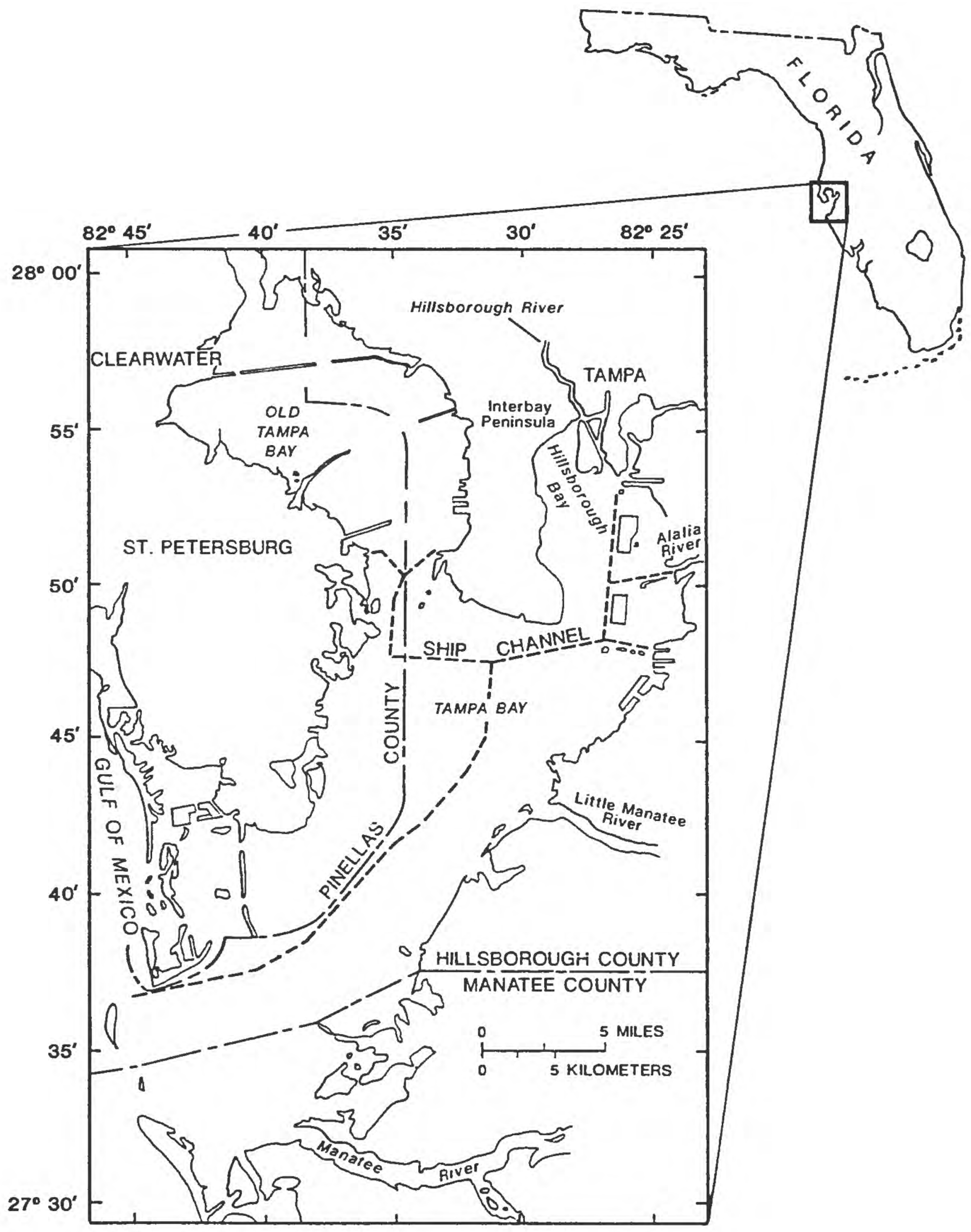

Figure 1. Location of Tampa Bay. 


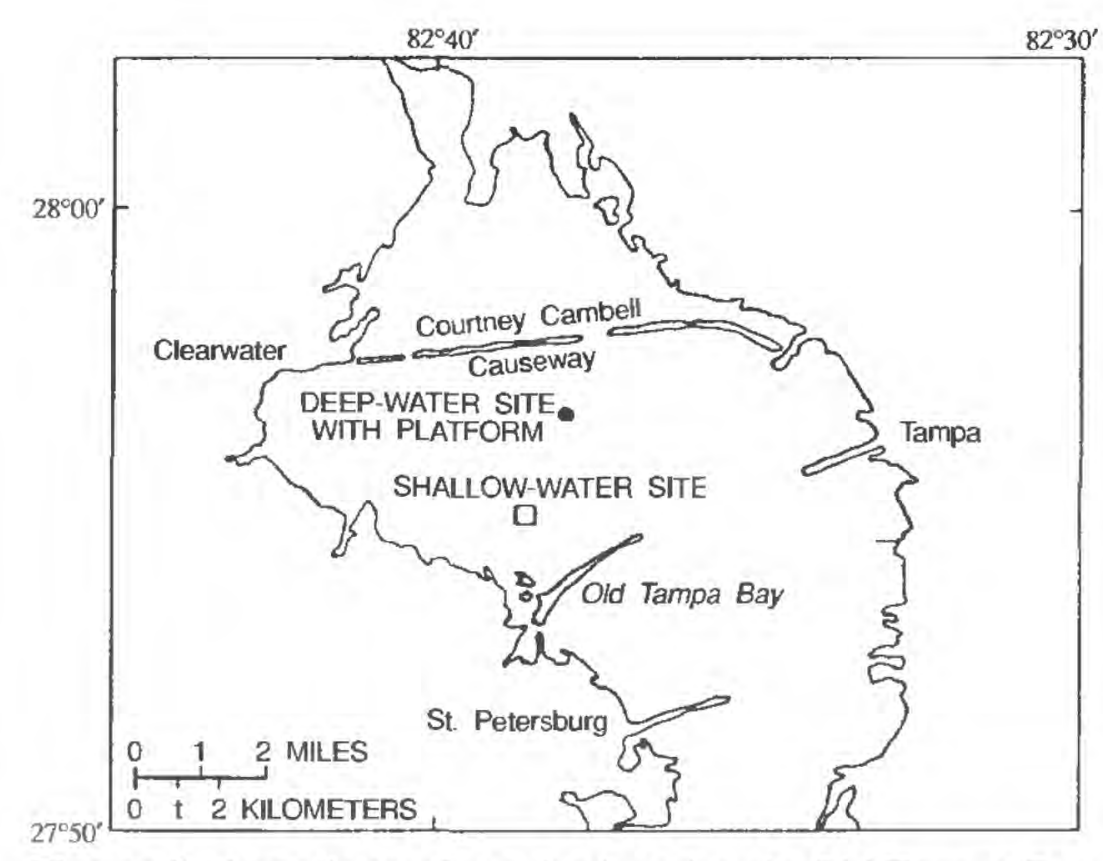

Figure 2. Locations of monitoring sites in Old Tampa Bay.
The horizontal arms of the instrument tree were $2 \mathrm{ft}$ long. A biaxial electromagnetic current meter mounted at the free end and an OBS sensor mounted at the midpoint were attached to each arm. In addition to a current meter and an OBS sensor, one of the horizontal arms also supported a pressure transducer for measuring water depth and wave activity. Wind velocity was measured with a cup anemometer and a wind vane that were mounted at the top of one platform pile at about $9 \mathrm{ft}$ above the steel deck. The sensor electronics, data recorder, and associated power supplies were housed in an aluminum shelter mounted at one corner of the steel deck.

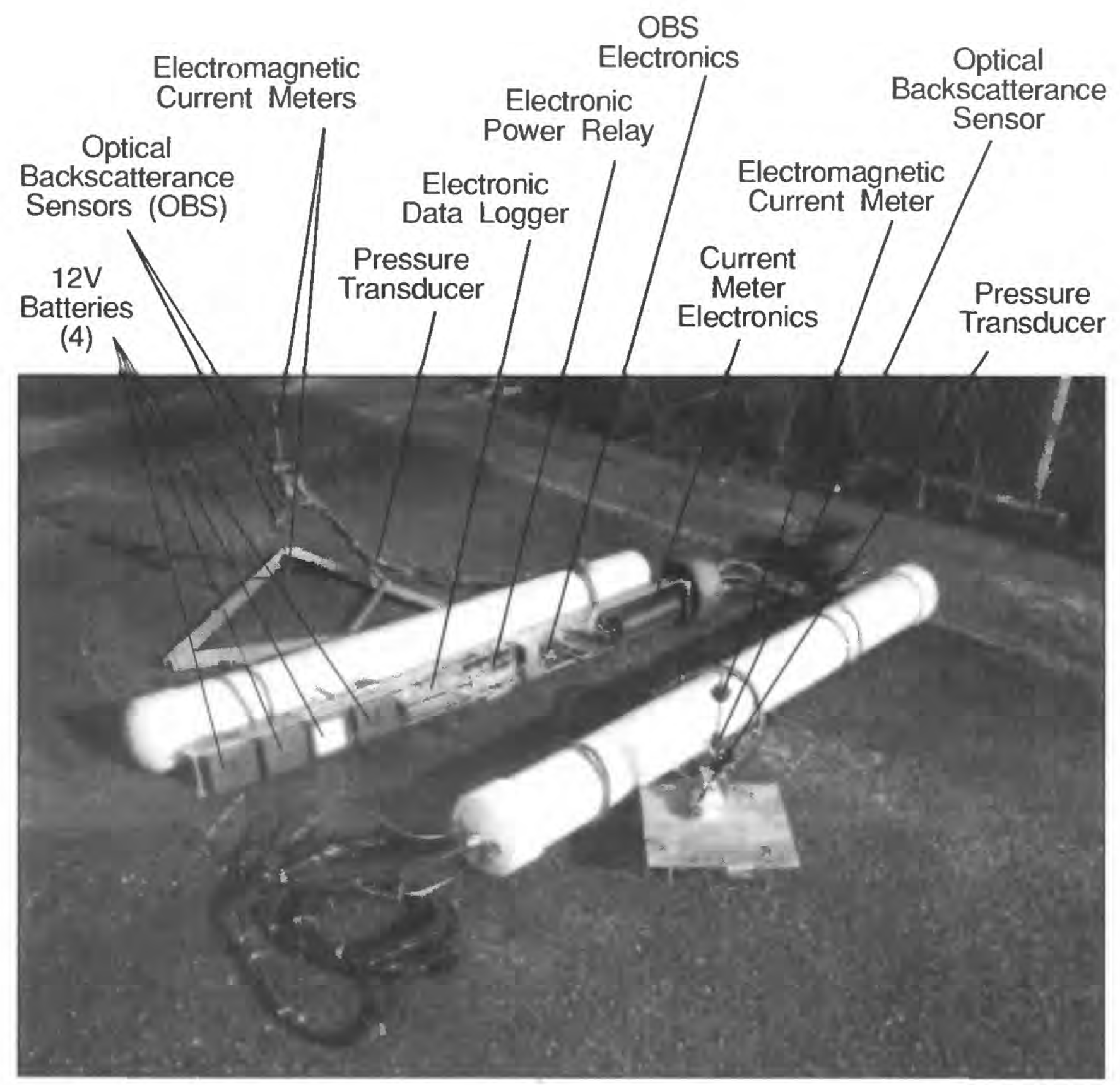

Figure 3. Submersible instrument packages. (Shallow-water package is in foreground. Deep-water package is in background.) 


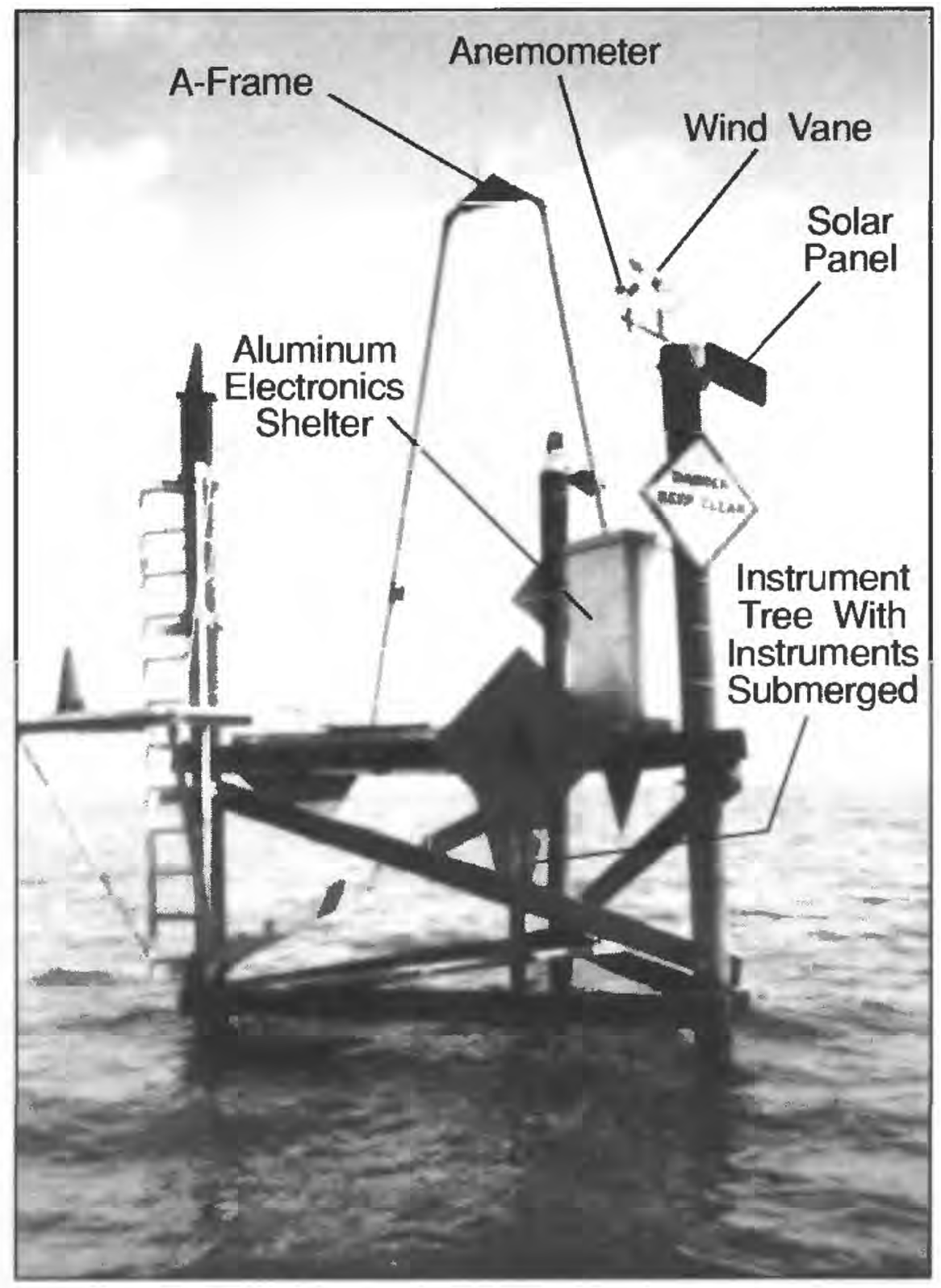

Figure 4. Deep water monitoring site platform in Old Tampa Bay.

\section{Instrument Deployment Strategy}

Two different deployment strategies were used in Old Tampa Bay during the study period. Instrumentation was continuously deployed during 1988 , and deployments were modified in 1989 to monitor suspected resuspension events caused by inclement weather systems. When initially deployed in August 1988 , the instrument tree was submerged continuously for about 2 months and data were transmitted from the deep-water platform in Old Tampa Bay to the USGS office in Tampa by a modem and a cellular phone. The platform data logger would activate the cellular telephone, and a personal computer (PC) in the USGS Tampa office would contact the cellular phone through a modem, establish electronic communication with the data logger, and issue commands for the data logger to transmit data. These data were then stored by the PC. Approximately 2 hours were required to transmit data from 24 burst samples. Both the platform and shore-based modems used an error checking protocol to ensure accurate data transmission; however, the data transmission would occasionally fail if the weather conditions were poor.

Analyses of the data available for October 1988 indicated that the OBS sensors had fouled, and when the sensors were cleaned by scuba divers, large amounts of marine growth were observed on all of the sensors. The output voltage from the OBS sensors began to increase as the sensors fouled, usually about 24 to 48 hours after cleaning (fig. 5), and the current meters fouled in about 7 days. The OBS sensors were 


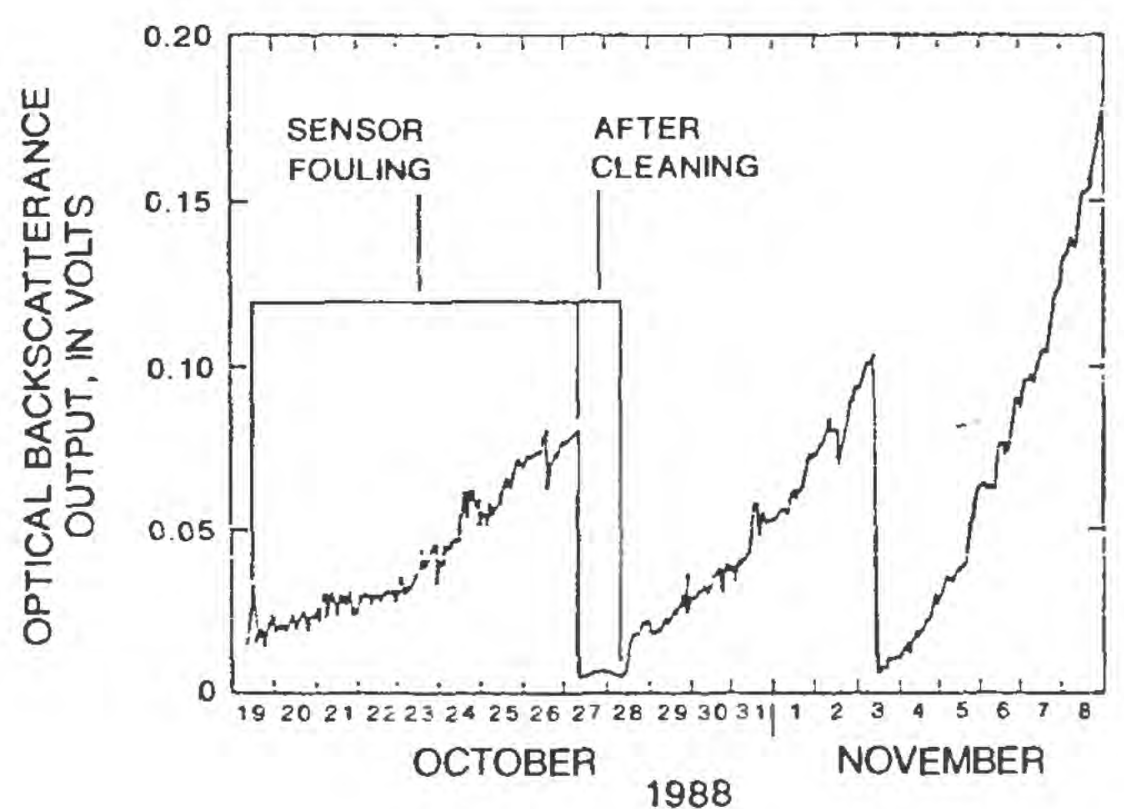

Figure 5. Optical backscatterance sensor response to fouling and after cleaning. (From Schoellhamer, 1993.)

coated with an antifoulant for optical surfaces

(Spinard, 1987) that only prevented barnacle growth on the optical surface. The cause of the fouling was an algal slime that would grow on the face of the sensors and affect their optical properties. In late 1988, when the instruments were submerged continuously, cleaning dives were conducted about every 2 weeks. The typical sudden decreases in OBS output shown in figure 5 occurred immediately after cleanings (Schoellhamer, 1993). Therefore, the OBS sensors were fouled most of the time and only data collected within 48 hours of cleaning will be discussed, with the exception of velocity data collected during the passage of Tropical Storm Keith when the OBS sensors were fouled but the current meter data were valid.

The sensor fouling, caused by marine growth on the continuously submerged sensors, proved to be a problem and a modification was required, so the instrument tree was attached to an A-frame and pulley system in December 1988. The instrument tree was suspended from an A-frame steel-pipe structure secured to the steel deck that allowed the instrument tree to be raised above the water surface for sensor cleaning and storage. Scnsor fouling required daily servicing trips to clean the sensors, so the cellular phone and modem were removed from the platform, the duration of deployments was reduced to less than 1 week, and a data storage module was exchanged daily during deployments in 1989 and 1990.
Initial analyses of the 1988 deep-water monitoring site usable data indicated that bottom sediment resuspension did not occur with normal or spring tidal currents, but sediment resuspension did occur during periods of increased wave activity generated by strong winds associated with weather systems. The typical sources for strong winds are cold fronts, tropical storms or hurricanes, and summer thunderstorms. Instrumentation was deployed in Old Tampa Bay before the anticipated arrival of selected meteorological events in 1989 and 1990 and then recovered several days later. At the beginning of each deployment, the platform instruments were tested, and the instrument tree was lowered into the water and secured to the steel deck of the platform. The submersible instrument package also was deployed at the shallow-water monitoring site beginning in November 1989. Daily servicing trips were made, weather permitting, to both sites for sensor cleaning and collection of water samples. The data storage module at the plat form was exchanged during the daily servicing trips. At the end of the deployment, the instrument tree was secured out of the water and the submersible instrument package was recovered.

\section{Hillsborough Bay}

Hillsborough Bay bottom sediments are generally fine sands in shallow water near the shoreline of the bay with silty fine sediments (particle diameter less than $63 \mu$ ) in the deeper waters (15-18 ft, excluding ship channels). A shallow-water monitoring site (site A, fig. 6, average depth about $3 \mathrm{ft}$ ) was located in an area of Hillsborough Bay with sandy bottom material at lat. $27^{\circ} 51^{\prime} 00^{\prime \prime} \mathrm{N}$ and long. $82^{\circ} 28^{\prime} 05^{\prime \prime} \mathrm{W}$ (Schoellhamer, 1992). Fine sediments comprise 2 percent of the bottom sediments at this site.

A decp-water monitoring site (site B, fig. 6, average depth about $15 \mathrm{ft}$ ) was located in the approximate ccnter of a large area of fine bottom sediments south of Long Shoal at lat. 27'51'34" N and long. $82^{\circ} 27^{\prime} 05^{\prime \prime}$ W (Schocllhamer, 1992). Fine sediments comprise 88 percent of the bottom sediments at this site.

A third site ncarly east of the deep-water site was used for additional resuspension monitoring in July and September 1991. This additional monitoring sitc (site $\mathrm{C}$, fig. 6 , average depth about $18 \mathrm{ft}$ ) was located about $\left(0.30\right.$ mi cast of site B at lat. 27 $51^{\prime} 34^{\prime \prime} \mathrm{N}$ and long. $82^{\circ} 26^{\prime} 47^{\prime \prime} \mathrm{W}$ (fig. 3). Bottom sediments at site C were similar to the sediments at site B (Schoellhamer, 1992). 


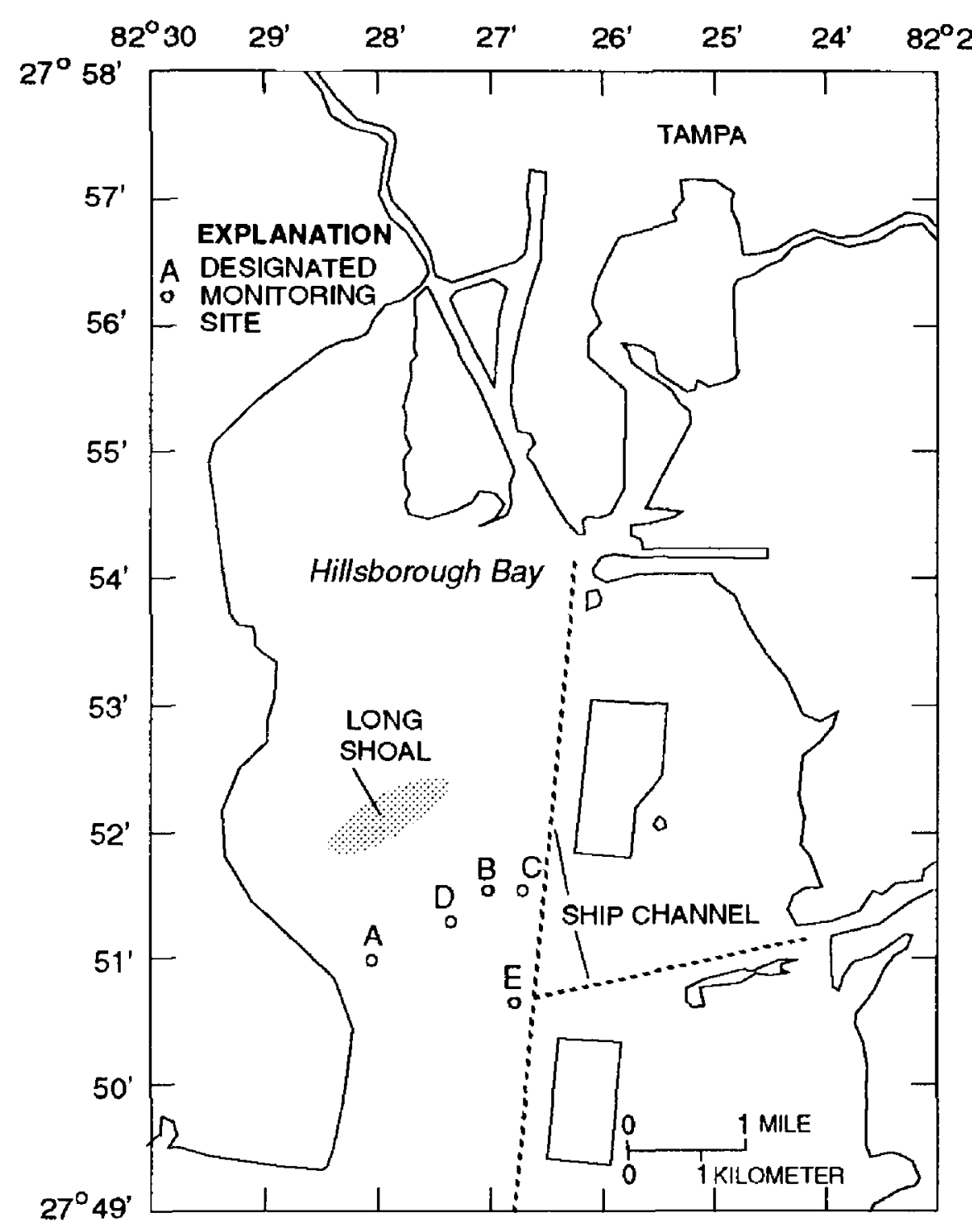

Figure 6. Locations of monitoring sites in Hillsborough Bay.

Water-surface monitoring was conducted from existing piles in Hillsborough Bay in September 1990 and March 1991. The water-surface monitoring site was used to measure surface waves at lat. $27^{\circ} 51^{\prime} 19^{\prime \prime} \mathrm{N}$ and long. 082 $27^{\prime} 24^{\prime \prime} \mathrm{W}$ in September 1990 (site D, fig. 6) and at lat. $27^{\circ} 50^{\prime} 40^{\prime \prime} \mathrm{N}$ and long. $82^{\circ} 26^{\prime} 51^{\prime \prime} \mathrm{W}$ in September 1991 (site E, fig. 6).

\section{Instrumentation}

The submersible instrument package deployed at the Old Tampa Bay shallow-water monitoring site also was deployed in Hillsborough Bay, and the Old Tampa Bay platform instrumentation was used to develop two additional submersible instrument packages for use in Hillsborough Bay during 1991. The Old Tampa Bay submersible instrument package was deployed at Hillsborough Bay deep-water monitoring site B in 1990 and at shallow-water site A during 1991. Instrumentation from the Old Tampa Bay platform was removed and used to develop two additional submersible instrument packages for use at deep-water monitoring sites $\mathrm{B}$ and $\mathrm{C}$ in Hillsborough Bay during
1991 (fig. 3). The two additional instrument packages consisted of two biaxial electromagnetic current meters, two OBS sensors, and a pressure transducer that were mounted on a diagonal arm that rises from a 3-ft equilateral triangle base. The triangular base was made from 2 -in. by 1 -in. angular aluminum fastened together with stainless steel bolts at the three corners. The sensor support arm was at the midpoint of one side of the base and rose at approximately a 45-degree angle from the horizontal towards the center of the triangle. The biaxial current meters were mounted vertically and end-1o-end approximately 1.9 and $0.5 \mathrm{ft}$ above the base. The OBS sensors were fastened to the current meters at elevations of 1.5 and $0.9 \mathrm{ft}$, and a strain-gage pressure transducer was attached near the bottom of the sensor support arm. Data acquisition, data storage, and sensor timing were controlled by an electronic data logger. Power was supplied by four 12-volt DC, 8-ampere-hour gel-cell batteries. These two instrument packages were deployed at sites $\mathbf{B}$ and $\mathrm{C}$ in Hillsborough Bay (fig. 6). A strain-gage pressure transducer was used at the surface wave monitoring sites (sites D and E).

\section{Instrument Deployment Strategy}

Instrument deployments in Hillsborough Bay were primarily designed to observe long waves generated by large vessels in the navigation channel. The initial instrument deployment at the Hillsborough Bay decp-water monitoring site in March 1990 indicated that tidal currents did not cause net sediment resuspension, but a vessel-generated long wave could resuspend bottom sediments. Burst measurements were collected and stored on the hour, and the minimum, maximum, mean, and standard deviation were stored every half-hour. A second deployment in September 1990 at the deep-water monitoring site and at site D (pressure transducer only) confirmed that tidal currents did not measurably resuspend bottom sediments and that large vessels in the navigation channel could generate long waves that were capable of resuspending bottom sediments. The instrumentation was set to record continuously at a once-per-second $(1-\mathrm{Hz}$ ) frequency during the 1-day deployment in September 1990.

Submersible instrument packages were deployed at the shallow- and deep-water monitoring sites in March 1991 to observe vessel-generated long waves and to monitor sediment resuspension during a winter storm. A pressure transducer was also 
deployed at site E (fig. 6) in March 1991 to monitor vessel-generated long waves. Experimental trawls were conducted at the deep-water monitoring site in May 1991 to sludy the effect of shrimp trawling on sediment resuspension. Water velocities, water depth, and concentrations of suspended solids were measured continuously and stored for 3 hours during and after the shrimp trawling experiment. The instruments at the deep-water monitoring site collected measurements every half-hour after the experiment was conpleted, and a floating automatic water sampler was used to collect water samples. Submersible instrumentation also was deployed at the shallow-water monitoring site during the shrimp trawling experiment in May 1991.

The data-collection program was modified in July 1991 so that data were collected continuously for 2 days, but were stored only if a long wave might have occurred. The minimum, nlaximum, mean, and standard deviation of the sensor outputs were independently stored every 10 minutes. The July 1991 deployment also included a third submersible instrument package at site $C$ east of the deep-water monitoring site (fig. 6). Submersible instrument packages also were deployed at sites A, B, and C in September 1991 to monitor sediment resuspension by vessel-generated long waves and by a weak storm system.

\section{Instruments}

Various electronic instruments were used for sediment resuspension monitoring at the selected study sites. Water velocities were measured using biaxial electromagnetic current meters. Suspended sediment concentrations were measured using optical backscatterance (OBS) sensors, and the OBS output voltages were calibrated using water sample analyses. Water depth and wave activity were measured using two types of pressure transducers. Electronic data loggers were used to time sensor on-times and to store data collected from the various instruments.

The current meters were routinely calibrated by the manufacturer or by USGS personnel at hydraulic facilities in Mississippi. The OBS sensors were calibrated in the Tampa laboratory, but were more accurately calibrated in the field when resuspension of bottom sediments occurred. The pressure transducers were calibrated for water depth by the manufacturer and checked by USGS personnel in Tampa.

\section{Description and Operation}

Resuspension monitoring instrumentation consisted of biaxial electromagnetic current meters, OBS sensors, and three types of pressure transducers. The biaxial current meters have a 2 -in. diameter rubberized sphere attached near the end of an 8-in. stainless-steel rod. The biaxial electromagnetic current meters measure water velocity using the Faraday principle of electromagnetic induction where a conductor (water) moving in a magnetic field (induced by the current sensor) produces a voltage that is proportional to the water velocity. The OBS sensors are thumb-size and have an optical window at the relative position of the thumbnail (Downing and others, 1981; Downing, 1983). The optical window is used to transmit an infrared pulse of light that is scattered or reflected by particles in the water to a distance of about 4 to 8 in. at angles up to 140 degrees in front of the window. Some of this scattered or reflected infrared light returns to the optical window where a receiver converts the backscattered infrared light to an output voltage. The output voltage is proportional to the concentration of suspended solids and the turbidity in the water column. Calibration of the OBS output to concentrations of suspended solids will vary depending on the size and optical properties of the suspended solids; therefore, the OBS sensors must be calibrated either in the field or in a laboratory with the same suspended material that is found in the field. A vibrating-wire pressure transducer was initially used at the Old Tampa Bay deep-water monitoring site to measure water depth and wave activity and was eventually replaced with a strain-gage pressure transducer. Strain-gage pressure transducers were used exclusively at the Old Tampa Bay shallow-water monitoring site and at the Hillsborough Bay monitoring sites to measure water depth and wave activity.

Data acquisition, data storage, and sensor timing were controlled by an electronic data logger. A burst sample of the current meter outputs, OBS sensor outputs, and the pressure-transducer output was collected during deployments at the monitoring study sites. The burst sample consisted of 1-second data of all sensor outputs for the duration of the sampling interval. Either the entire burst sample was stored on an external data storage module or the minimum, maximum, mean, and standard deviations of the sensor outputs from the burst measurement were stored in the data logger, depending upon the programming of the data logger. 
Light attenuation in the water column was calculated for selected deployments based on light radiance or irradiance measurements. Light radiance and irradiance were measured with a quantum radiometer/photometer during selected deployments. Radiance was measured using a flat sensor, whereas irradiance was measured using multiple spherical sensors. When the two types of sensors were used concurrently, the calculated light attenuation coefficients compared within 10 percent of each other.

\section{Calibration and Output of Electromagnetic Current Meters}

The voltage output from the electromagnetic current meters must be calibrated to determine water velocities. The meters have two separate output voltages, one for each orthogonal velocity component, which are linearly related to the water velocity. The manufacturer calibrated the current meters after manufacture and repairs, and the calibration values were checked annually by the USGS hydraulics laboratory at the Stennis Space Center in Mississippi. The USGS calibration check generally agreed within 10 percent of the stated calibration values of the manufacturer. If a USGS calibration was available, that value was used to convert meter voltages to water velocities; otherwise, the calibration coefficient of the manufacturer was used.

The current meters were used to verify wave activity calculated from the pressure transducer data, and sometimes used to calculate wave activity if the pressure transducer had failed. When the current meter outputs were used to calculate wave activity, the frequency response of the current meters was limited by its filter network. The frequency response of the electromagnetic current meters used in this study is reduced when measuring short period water waves, such as wind-waves with 2- to 4-second time periods. The current meter output response to short period water waves is reduced by an electronic filter network used to suppress a $60-\mathrm{Hz}$ carrier signal that is inherent in the current meter design. At wind-wave time periods of interest to this study, the gain (output voltage) of the meters is reduced by the electronic filter so that actual velocities are greater than recorded values. Velocities can be mathematically corrected for electronic filtering (Guza, 1988), and the velocity data collected were corrected for this study.
Calibration, Response Threshold, and Biological
Interference of Optical Backscatterance Sensors

The OBS sensors needed to be calibrated to relate OBS output voltages to suspended sediment concentrations at the study sites. The sensors were calibrated using the results from water sample analyses of suspended sediment concentrations that were collected during equipment deployments. The relatively low concentrations of ambient suspended sediments at the study sites sometimes made the determination of a resuspension event difficult to assess and the analyses of OBS data were complicated more by the fouling of the sensor windows. OBS sensors were left unattended for periods of about two weeks during 1988 to 1989 , and the analysis of OBS data indicated that a gradual fouling of the sensor windows was occurring during these deployments. Despite these limitations, the OBS sensors provided sufficiently reliable data that allowed the determination of sediment resuspension events.

Water samples were collected at the times of electronic equipment deployments for the calibration of OBS sensors and for the determination of sediment resuspension. More comprehensive monthly waterquality sampling occasionally coincided with resuspension monitoring for 1 day of the deployment. Three methods of water-sample collection were used depending on the type of data required. Two types of peristaltic pumps and a Kemmerer tube were used to collect point samples from discrete depths, whereas a weighted 1-L bottle was used for depth-integrated sample collection. Discrete water samples used for the calibration of the OBS sensors were collected daily at the deep-water monitoring sites from each OBS sensor depth into 1-L and 250-mL hottles using a peristaltic pump connected to tygon tubing. OBS calibration samples were collected at the shallow-water monitoring sites with a Kemmerer tube and then transferred directly to 1-L and 250-mL plastic bottles. Watcr samples were analyzed at a USGS laboratory for total and volatile suspended solids, turbidity, specific conductance, and dissolved chloride using methods described in Fishman and Friedman (1989).

A continuous water-sample collection technique was required for monitoring suspended solids during storm events; therefore, an automatic water sampler was secured in one comer of the steel deck at the Old Tampa Bay platform, or the automatic sampler was deployed in an annular float at site B in Hillsborough Bay during each deployment. An automatic water 
sampler, connected to nylon reinforced teflon tubing or rubber tubing, collected an OBS calibration point sample every hour during most instrument deployments. The automatic water sampler was timed to sample concurrently with the electronic sensors. Water samples were transferred to 1-L plastic bottles for shipment to a USGS laboratory where the samples were analyzed for total and volatile suspended solids, turbidity, and specific conductance using methods described in Fishman and Friedman (1989).

Ambient concentrations of suspended solids were often below the response threshold of the OBS sensors, and biological interference with the sensors was a potential problem. The hydrodynamic energy in Old Tampa Bay and its tributaries is small in magnitude, and the ambient concentrations of suspended solids also are small, about 10 to $40 \mathrm{mg} / \mathrm{L}$. Bccause of the response threshold of OBS sensors, accurate interpretation of OBS data may be difficult except during episodic events that resuspend bottom sediments. Suspended solids might not be detected, and backscatterance from phytoplankton may be detected when suspended solids are at ambient concentrations in Old Tampa Bay. The OBS sensor electronics were factory adjusted in mid-1989 to improve their sensitivity, but the problem of low ambient concentrations was not eliminated. In addition to low ambient concentrations of suspended solids, eutrophic conditions encourage biological activity that can interfere with OBS data (fig. 5), so daily cleaning was necessary for the collection of accurate data. The range of concentrations of suspended solids in water samples was sometimes insufficient to accurately calibrate the OBS outputs to concentrations of suspended solids. When calibrations were not available or insufficient, the OBS output voltages were used to qualitatively identify sediment resuspension. When calibration of the OBS outputs was possible, a calibration curve was calculated and suspended-solids concentrations were used to quantitatively identify sediment resuspension. An example of a calibration curve for an OBS sensor is shown in figure 7. In addition to low ambient suspended-solids concentrations and OBS sensor fouling, occasional high spikes (short duration increases in OBS output voltages) would occur during the hurst sample collection. The high spikes were attributed to fish swimming past the OBS sensors during a burst sample. Regular sensor maintenance and systematic data analysis were used to minimize abnormalities in OBS data.

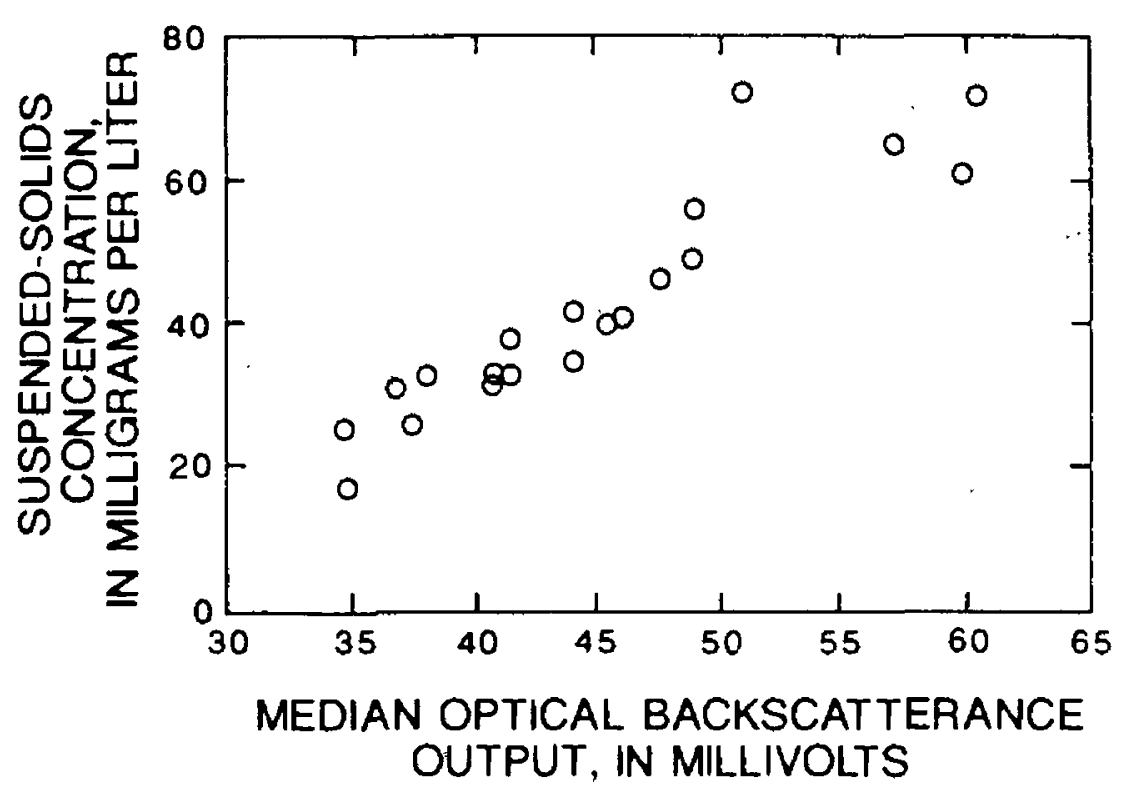

Figure 7. Example of an optical backscatterance calibration curve. (From Schoellhamer, 1993.)

\section{RESUSPENSION MONITORING ACTIVITIES IN OLD TAMPA BAY}

Resuspension monitoring data for Old Tampa Bay were collected using a series of equipment deployments. For each deployment, wind speed and azimuth, water depth, north water velocity components, east water velocity components, and the output voltages of the OBS sensors were measured. A table summarizing operating sensor types and their respective elevations above the bottom is presented for each deployment. An example of a typical data set is presented for the November 1990 deployment (figs. 812).

\section{Monitoring in 1988}

Resuspension monitoring equipment were first deployed at the deep-water site platform on August 5, 1988, and data collection began on August 17, 1988. As mentioned previously, data transmission was initially unreliable so large gaps in the data exist. Because of fouling, only the first 48 hours of OBS data after cleanings were reliable and those are the data that will he discussed. Instrumcnts were cleaned on Octoher 18, October 27, November 3, November 17, and November 30 . In addition, data collected from 0001 hours on November 21 to 2300 hours on Novemher 24, which includes the passage of Tropical Storm Keith, will be discussed despite the fouled OBS sensors because the current meter data during the storm may be of interest. Table 1 summarizes the 
Table 1. Periods and summary of data collection in Old Tampa Bay for 1988

[OBS, optical backscatterance]

\begin{tabular}{|c|c|c|c|}
\hline Date & $\begin{array}{l}\text { Reason for } \\
\text { instrument } \\
\text { deployment }\end{array}$ & Site & Type of data collected \\
\hline October $19-20,1988$ & Continuous monitoring & Deep & $\begin{array}{l}\text { Wind, hydrodynamic, } \\
\text { and OBS. }\end{array}$ \\
\hline October $27-29,1988$ & Continuous monitoring & Deep & $\begin{array}{l}\text { Wind, hydrodynamic, } \\
\text { and OBS. }\end{array}$ \\
\hline November 3-5, 1988 & Continuous monitoring & Deep & $\begin{array}{l}\text { Wind, hydrodynamic, } \\
\text { and OBS. }\end{array}$ \\
\hline November $17-19,1988$ & Continuous monitoring & Deep & $\begin{array}{l}\text { Wind, hydrodynamic, } \\
\text { and OBS. }\end{array}$ \\
\hline November $21-24,1988$ & $\begin{array}{l}\text { Continuous monitoring } \\
\text { and Tropical Storm } \\
\text { Keith }\end{array}$ & Deep & Wind and hydrodynamic. \\
\hline $\begin{array}{l}\text { November } 30- \\
\text { Decernber } 2,1988\end{array}$ & Continuous monitoring & Deep & $\begin{array}{l}\text { Wind, hydrodynamic, } \\
\text { and OBS. }\end{array}$ \\
\hline
\end{tabular}

reason for deployments, the sites where data were collected, and the type of data that were collected. All times are Eastern Standard Time.

Some of the instruments deployed in August 1988 failed to operate reliably. Current meters 0.7 and $5.9 \mathrm{ft}$ above the bed had failed and were recovered on October 18. An OBS sensor $5.9 \mathrm{ft}$ above the bed did not work. After all of the instruments were recovered in 1989, it was discovered that a current meter $1.5 \mathrm{ft}$ above the bed had unknowingly been bent, possibly during installation, and, consequently, the current meter data were unreliable. Table 2 lists the elevations of operational velocity, OBS, and pressure sensors for the 1988 deployments. The cups of the anemometer that was used in 1988 would spin easily, but the generator would not produce a voltage for fewer than about 100 revolutions per minute. Therefore, the threshotd wind speed was about $11.5 \mathrm{ft} / \mathrm{s}$, and recorded wind speeds less than $11.5 \mathrm{ft} / \mathrm{s}$ are assumed to be inaccurate. Wind speeds at the platform coinpared favorably with wind speeds recorded at Tampa International Airport (approximately $6 \mathrm{mi}$ from the deep-water site) during Tropical Storm Keith in November 1988, so the recorded wind speeds are reliable for the higher values of most interest for this study.

\section{October 19-20, 1988}

The platform instruments were cleaned on October 18, but a power supply problem was not corrected until October 19. Therefore, hourly data collected from 1000 hours on October 19 to 1000 hours on October 20 , the second day after the instru-
Table 2. Operational deep-water monitoring site instrument elevations above the bed in Old Tampa Bay, October 19-20 and 27-29; November 3-5, 17-19, and 21-24; and November 30-December 2, 1988

[X, operational; -, not operational]

\begin{tabular}{cccc}
\hline $\begin{array}{c}\text { Elevation } \\
\text { feet }\end{array}$ & $\begin{array}{c}\text { Velocity } \\
\text { data }\end{array}$ & $\begin{array}{c}\text { Optical } \\
\text { backscatterance } \\
\text { data }\end{array}$ & $\begin{array}{c}\text { Pressure } \\
\text { data }\end{array}$ \\
\hline 0.7 & - & $\mathrm{X}$ & \\
1.5 & - & $\mathrm{X}$ & \\
3.0 & $\mathrm{X}$ & $\mathrm{X}$ & $\mathrm{X}$ \\
5.9 & - & - & \\
9.7 & $\mathrm{X}$ & $\mathrm{X}$ & \\
\hline
\end{tabular}

ment cleaning, are reliable. Water-quality samples were collected at 1030 hours on October 19 and were analyzed for total and volatile suspended solids, turbidity, color, dissolved organic carbon, specific conductance, and chlorophyll $a$. Water samples were depth-integrated through the top $6.5 \mathrm{ft}$ and through the entire water column (water surface to bottom) using a weighted glass bottle. Net sediment resuspension was not detected. Table 2 lists the elevations at which water velocity and OBS data were collected.

\section{October 27-29, 1988}

The platform instruments were cleaned at 0830 hours on October 27. Data collected from 090) hours on October 27 to (0900 hours on October 29 are reliable. An increase in OBS output on October 28 and 29 was probably due to sensor fouling. Net sediment resuspension was not detected. 


\section{November 3-5, 1988}

The platform instruments were cleaned at 1130 hours on November 3. Dala collected from 1200 hours on November 3 to 1200 hours on November 5 are reliable. An increase in OBS output on November 4 and 5 was probably due to sensor fouling. Net sediment resuspension was not detected.

\section{November $17-19,1988$}

The platform instruments were cleaned at 1030 hours on November 17. Data collected from 1100 hours on November 17 to 1100 hours on November 19 are reliable. An increase in OBS sensor output $0.7 \mathrm{ft}$ above the bed on November 18 and 19 was probably due to sensor fouling. Net sediment resuspension was not detected.

\section{November 21-24, 1988}

Tropical Storm Keith made landfall in Sarasota, approximately $45 \mathrm{mi}$ south of the deep-water monitoring site, early on the morning of November 23, 1988. Winds from the storm began to affect the Tampa Bay area late in the evening on November 21 . This was the first tropical storm since 1985 to affect the Tampa Bay area and the only tropical storm that approached Tampa Bay in 1988. The instruments had not bcen cleaned since November 17 . The data from the current meters are believed to be accurate; unfortunately, the OBS sensors were fouled. Data collected from 0001 hours on November 21 to 2300 hours on November 24 include the storm and ambient conditions before and after the storm. Table 2 lists the elevations where water velocity and OBS data (from fouled sensors) were collected. An increase in OBS sensor output over the 4-day period was probably caused by sensor fouling; the cause of a rapid decrease in OBS output on November 24 is unknown. Net sediment resuspension most likely occurred, although OBS data were difficult to interpret due to sensor fouling.

\section{November 30-December 2, 1988}

The platform instruments were cleaned near midday on November 30. Data collected from 0500 to 1300 hours on November 30 are unavailable because of data transmission problems. Data collected from 1400 hours on November 30 to 1200 hours on December 2 are reliable. Median OBS values at $1.5 \mathrm{ft}$ above the bed at 1800 hours on November 30 and $3.0 \mathrm{ft}$ above the bed at 0500 hours on December 2 were higher than ambient values. The probable explanation is that a reflective object, most likely a fish, was in front of the affected sensors at those times. An increase in OBS sensor output at $0.7 \mathrm{ft}$ above the bed on December 2 was probably caused by sensor fouling. Net sediment resuspension was not detected.

\section{Monitoring in 1989-90}

Resuspension monitoring instrumentation was deployed in 1989 and 1990 in Old Tampa Bay prior to the arrival of a forecast episodic event, such as a tropical storm, a cold front, or a severe thunderstorm. Deployments were made September 20-21, 1989, November 28-December 1, 1989, March 7-10, 1990, July 9-13, 1990, October 9-12, 1990, and November 28-December 3, 1990. Table 3 summarizes the reason for deployments, the sites where data were collected, and the type of data that were collected.

\section{September 20-21, 1989}

Hurricane Hugo passed over Puerto Rico on September 18, 1989, and continued toward the Atlantic coastline of the southeastern United States. Instrumentation at the Old Tampa Bay platform was deployed on the morning of September 20 in anticipation of the possible arrival of Hurricane Hugo. The submersible instrument package had not yet been built, so data were not collected at the shallow-water monitoring site.

Hugo was approaching South Carolina on the morning of Septcmber 21 and was not expected to affect the Tampa area, so the instrumentation was recovered.

Data from the dcep-water monitoring site were collected from 1100 hours on September 20 to 0900 hours on September 21 . The east velocity component of the current meter $0.9 \mathrm{ft}$ above the bed only operated from 1600 to 1800 hours on September 20 because of a faulty connector. An OBS sensor $1.5 \mathrm{ft}$ above the bottom failed to operate, and the automatic water sampler was not deployed. Table 4 lists the elevations above the bed where water vclocity and OBS data were collected at the plat form. Discrete water samples were collected for the calibration of OBS sensor outputs during this deployment, but the number of water samples collected and the range of suspended-solids concentrations were not sufficiently distributed to calibrate the OBS sensors. Net sediment resuspension was not detected. 
Table 3. Periods and summary of data collection in Old Tampa Bay for 1989 and 1990

[OBS, optical backscatterance]

\begin{tabular}{|c|c|c|c|}
\hline Date & $\begin{array}{l}\text { Reason for instrument } \\
\text { deployment }\end{array}$ & Site & Type of data collected \\
\hline September 20-21, 1989 & Hurricane Hugo & Deep & Wind, hydrodynamic, and OBS. \\
\hline $\begin{array}{l}\text { November } 28- \\
\text { December } 1,1989\end{array}$ & Cold front & $\begin{array}{l}\text { Deep } \\
\text { Shallow }\end{array}$ & $\begin{array}{l}\text { Wind, water velocities, OBS, and } \\
\text { calculated suspended solids. }\end{array}$ \\
\hline March 7-10, 1990 & Cold front & Deep & $\begin{array}{l}\text { Water velocities, OBS, and calcu } \\
\text { lated suspended solids. }\end{array}$ \\
\hline July 9-13, 1990 & Thunderstorms & $\begin{array}{l}\text { Deep } \\
\text { Shallow }\end{array}$ & $\begin{array}{l}\text { Wind, hydrodynamic, OBS, and } \\
\text { light attenuation coefficients. }\end{array}$ \\
\hline October $9-12,1990$ & $\begin{array}{l}\text { Tropical Storm } \\
\text { Marco }\end{array}$ & $\begin{array}{l}\text { Deep } \\
\text { Shallow }\end{array}$ & $\begin{array}{l}\text { Wind, water } \\
\text { velocities, and suspended-solids } \\
\text { concentrations. }\end{array}$ \\
\hline $\begin{array}{l}\text { November 28- } \\
\text { December 3, } 1990\end{array}$ & Cold front & $\begin{array}{l}\text { Deep } \\
\text { Shallow }\end{array}$ & $\begin{array}{l}\text { Wind, water velocities, and light } \\
\text { attenuation coefficients. }\end{array}$ \\
\hline
\end{tabular}

\section{November 28-December 1, 1989}

Electronic sensors were deployed at the deepwater platform site from 1600 hours on November 28 , 1989, until 1100 hours on December 1, 1989 and at the shallow-water site from 1500 hours on November 29 to 1300 hours on November 30 in anticipation of an approaching weather system. A fall-season cold front, bringing strong northerly winds, was expected to pass through the Tampa Bay area between November 28 and November 30 . The cold front passed the Tampa Bay area early on November 30,1989 . Reliable data were collected from 1600 hours on November 28 , 1989, through 1800 hours on November 30,1989 , at the deep-water monitoring site and from 1500 hours on November 29 through 1300 hours on November 30, 1989, at the shallow-water monitoring site. The deep-water platform pressure transducer

Table 4. Operational deep-water monitoring site instrument elevations above the bed in Old Tampa Bay, September 20-21, 1989

[X, operational; 1, intermittant; -; not operational]

\begin{tabular}{cccc}
\hline $\begin{array}{c}\text { Elevation } \\
\text { (feet) }\end{array}$ & $\begin{array}{c}\text { Velocity } \\
\text { data }\end{array}$ & $\begin{array}{c}\text { Optical } \\
\text { backscatterance } \\
\text { data }\end{array}$ & $\begin{array}{c}\text { Pressure } \\
\text { data }\end{array}$ \\
\hline 0.9 & $\mathrm{I}$ & $\mathrm{X}$ & \\
1.5 & $\mathrm{X}$ & - & \\
3.1 & $\mathrm{X}$ & $\mathrm{X}$ & $\mathrm{X}$ \\
5.9 & $\mathrm{X}$ & $\mathrm{X}$ & \\
9.5 & $\mathrm{X}$ & $\mathrm{X}$ & \\
\hline
\end{tabular}

dewatered when the instrument tree was raised for cleaning and produced an erroneous output until the transducer refilled with water. The current meters 0.9 and $1.5 \mathrm{ft}$ above the bed did not operate. A power supply relay failed to operate from 1800 hours on November 30 until 1100 hours on December 1, 1989, and subsequently caused the failure of all three operable current meters at the deep-water site. The OBS sensor $1.5 \mathrm{ft}$ ahove the bed did not function, and the automatic water sampler did not operate correctly. Table 5 lists the velocity sensor and OBS sensor elevations of the operational instruments at the deep-water monitoring site during the deployment.

One water-sample transect, which consisted of the shallow-water and the deep-water monitoring sites as endpoints with three equidistant collection points in between, was conducted from 1415 to 1441 hours on November 30, 1989. Discrete water samples were collected daily for the calibration of OBS sensor outputs during this deployment. Net sediment resuspension could have occurred at the deep-water monitoring site.

This was the first deployment for the submersible instrument package at the shallow-water monitoring site. An electromagnetic current meter $0.85 \mathrm{ft}$ above the bed and an OBS sensor $0.33 \mathrm{ft}$ above the bed collected reliable data. The strain-gage pressure transducer did not function due to a damaged sensor. Discrete water samples were collected daily at the shallow-water monitoring site for the calibration of OBS sensor outputs. Net sediment resuspension was detected at the shallow-water monitoring site (Schoellhamer, 1990). 
Table 5. Operational deep-water monitoring site instrument elevations above the bed in Old Tampa Bay, November 2830, 1989

[X, operational; 1 , intermittant; -, not operational]

\begin{tabular}{cccc}
\hline $\begin{array}{c}\text { Elevation } \\
\text { (feet) }\end{array}$ & $\begin{array}{c}\text { Velocity } \\
\text { data }\end{array}$ & $\begin{array}{c}\text { Optical } \\
\text { backscatterance } \\
\text { data }\end{array}$ & $\begin{array}{c}\text { Pressure } \\
\text { data }\end{array}$ \\
\hline 0.9 & - & $\mathrm{X}$ & \\
1.5 & - & - & \\
3.1 & $\mathrm{I}$ & $\mathrm{X}$ & \\
5.9 & $\mathrm{I}$ & $\mathrm{X}$ & - \\
9.5 & $\mathrm{I}$ & $\mathrm{X}$ & \\
\hline
\end{tabular}

\section{March 7-10, 1990}

Resuspension monitoring equipment was deployed prior to the expected passage of a cold front through the Tampa Bay area on March 8. Electronic sensors were deployed at the platform site from 1400 hours on March 7 through 1000 hours on March 10, 1990. Strong southerly winds preceding the front produced rough-water conditions that prevented the deployment of the shallow-water instrument package. The frontal system passed through the Tampa Bay area on March 8, 1990. Reliable data were collected at the deep-water site from 1400 hours on March 8 until 1000 hours on March 10, 1990. The instrument tree was reconfigured in an effort to reduce data losses due to malfunctioning instruments. Current meters and an OBS sensor were mounted on opposing horizontal arms, providing a redundancy in measurements of water velocity at the two lowest elevations $(0.8$ and $2.3 \mathrm{ft}$ ), and the highest elevation ( $6.0 \mathrm{ft})$ horizontal arm was configured as before with a single arm and a single set of instruments.

Some of the deep-water monitoring site instrumentation failed to operate properly during this deployment. Depth measurements from the pressure transducer (vibrating-wire type) from 1100 through 1400 hours on March 9, 1990, were below acceptable values, probably due to the dewatering of the transducer. A current meter $0.8 \mathrm{ft}$ above the bed experienced a malfunction that caused a full-scale output ( +5 volts DC) and in turn caused the dat a logger to store erroneous data from 1400 hours on March 7 to 1300 hours on March 8, 1990. Current meters at 0.8 $\mathrm{ft}$ above the bed and a current meter at $2.3 \mathrm{ft}$ did not function properly for the duration of the deploy- ment. The current meter $6.0 \mathrm{ft}$ above the bed was affected by a concurrent velocity verification measurement at 1200 and 1300 hours on March 9. OBS sensors $0.8 \mathrm{ft}$ above the bed did not operate properly for the duration of the deployment, and an OBS sensor $2.3 \mathrm{ft}$ above the bed was malfunctioning during the last 24 hours of the deployment. The deep-water site operational instruments and their respective elevations above the bottom are listed in table 6 . Discrete water samples were collected daily for the calibration of OBS sensor outputs during this deployment. One water-sample transect, which consisted of the deep-water and the shallow-water monitoring sites as endpoints with three equidistant collection points in between, was conducted from 1250 to 1310 hours on March 8. Net sediment resuspension was detected at the deep-water monitoring site.

\section{July 9-13, 1990}

Thunderstorms in Florida are most numerous in July, and high winds and waves associated with these local weather systems are possible sediment resuspension mechanisnis; therefore, a resuspension monitoring deployment was conducted July 9-13, 1990. Several strong storms occurred during the deployment.

Reliable data were recorded at the deep-water monitoring site from 0800 hours on July 11 through 1000 hours on July 13,1990 . The data storage module was not properly cleared bofore the deployment and the data collected during the first 2 days ( 1400 hours on July 9 to 0700 hours on July 11) were lost. Reliable data were collected by current meters at elevations of $0.8 \mathrm{ft}$ and $2.3 \mathrm{ft}$ above the bed. Two OBS sensors 0.8 and $2.3 \mathrm{ft}$ above the bed malfunctioned when deployed and did not produce any reliable data. The pressure transducer suffered discontinuities in output due to

Table 6. Operational deep-water monitoring site instrument elevations above the bed in Old Tampa Bay, March 7-10, 1990

[X, operational: l, intemittant; -, not operational]

\begin{tabular}{cccc}
\hline $\begin{array}{c}\text { Elevation } \\
\text { (feet) }\end{array}$ & $\begin{array}{c}\text { Velocity } \\
\text { data }\end{array}$ & $\begin{array}{c}\text { Optical } \\
\text { backscatterance } \\
\text { data }\end{array}$ & $\begin{array}{c}\text { Pressure } \\
\text { data }\end{array}$ \\
\hline 0.8 & $--^{-1}$ & $--^{1}$ & \\
2.3 & $-\mathrm{X}^{1}$ & $-\mathrm{I}^{1}$ & \\
6.0 & $\mathrm{X}$ & $\mathrm{X}$ & - \\
\hline
\end{tabular}

${ }^{1}$ Dual instrumentation. 
resubmersion, but the data were smoothed during data processing. Reliable light irradiance was measured continuously using three spherical sensors and a data logger. One light sensor was mounted approximately $11 \mathrm{ft}$ above the steel deck, and two sensors were niounted at fixed elevations above the bed that placed the irradiance scnsors within the top $6 \mathrm{ft}$ of water. The deep-water monitoring site operational instruments and their respective clevations above the bottom are listed in table 7. Discrete water samples were collected daily for the calibration of OBS sensor outputs during this deployment. Net sediment resuspension was not detected at the platform site.

The shallow-water monitoring site instrument paekage was deployed from 1030 hours on July 9 to 0930 hours on July 13. The pressure transducer did not function properly. Burst data were collected every half-hour throughout the deployment at the shallowwater monitoring site. An electromagnetic current meter $0.85 \mathrm{ft}$ above the bed and an OBS sensor $0.33 \mathrm{ft}$ above the bed collected reliable data. Discrete depth water samples were collected daily for the calibration of OBS sensor outputs during this deployment. Net sediment resuspension was detected at the shallowwater monitoring site during a thunderstorm.

\section{October 9-12, 1990}

Resuspension monitoring instruments were deployed in anticipation of Tropical Storm Marco, a late-season tropical storm that was forecast to affect the Tampa Bay area around October 10 or 11. Tropical Storm Marco moved north along the west-central coast of Florida on October 11 and produced winds of approximately $33 \mathrm{mi} / \mathrm{h}$ at the deep-water monitoring site.

Table 7. Operational deep-water monitoring site instrument elevations above the bed in Old Tampa Bay, July 11-13, 1990

[X, operational; I, intemittant; -, not operational]

\begin{tabular}{cccc}
\hline $\begin{array}{c}\text { Elevation } \\
\text { (feet) }\end{array}$ & $\begin{array}{c}\text { Velocity } \\
\text { data }\end{array}$ & $\begin{array}{c}\text { Optical } \\
\text { backscatterance } \\
\text { data }\end{array}$ & $\begin{array}{c}\text { Pressure } \\
\text { data }\end{array}$ \\
\hline 0.8 & $--^{1}$ & $-\mathrm{X}^{1}$ & \\
2.3 & $\mathrm{X} \mathrm{X}^{1}$ & $-\mathrm{X}^{1}$ & \\
6.0 & $\mathrm{X}$ & $\mathrm{X}$ & $\mathrm{X}$ \\
\hline
\end{tabular}

${ }^{1}$ Dual instrumentation.
Some of the deep-water monitoring site instrumentation failed to operate properly, resulting in a loss of data. The platform pressure transducer had become dewatered and its output never fully recovered, invalidating all pressure data. Two current meters $0.8 \mathrm{ft}$ above the bed were being repaired by the manufacturer, and one of the current meters $2.3 \mathrm{ft}$ above the bed had been bent and subsequently straightened, but data recorded by the meter proved to be unreliable. The only reliable current data were recorded by the current meter $6.0 \mathrm{ft}$ above the bed. The two OBS sensors $0.8 \mathrm{ft}$ above the bed and one OBS sensor $2.3 \mathrm{ft}$ above the bed malfunctioned, possibly due to water in an underwater connector. The deep-water monitoring site operational instruments and their respective elevations above the bottom are listed in table 8 .

Water samples were collected automatically at the plat form from 2100 hours on October 9 through 1000 hours on Octoher 12, 1990), and additional OBS calibration samples also were collected throughout the deployment. One water-sample transect, which consisted of five equidistant collection points with the deep-water and the shallow-water monitoring sites as endpoints, was conducted from 1144 to 1159 hours on October 12. Net sediment resuspension was detected at the deep-water monitoring site.

The submersible instrument package was positioned at the shallow-water monitoring site after the deep-water monitoring site instruments were deployed and checked. The shatlow-water current meter did not function from 1800 hours on

October 9, 1990, until 1100 hours on

October 10, 1990, but operated for the remainder of the deployment. A buoy line attached to the instrument stand coiled around the OBS scnsor and apparently affected the OBS output beginning late in the

Table 8. Operational deep-water monitoring site instrument elevations above the bed in Old Tampa Bay, October 9-12, 1990

[X. operational; l, intemittant; -, not operational]

\begin{tabular}{cccc}
\hline $\begin{array}{c}\text { Elevation } \\
\text { (feet) }\end{array}$ & $\begin{array}{c}\text { Velocity } \\
\text { data }\end{array}$ & $\begin{array}{c}\text { Optical } \\
\text { backscatterance } \\
\text { data }\end{array}$ & $\begin{array}{c}\text { Pressure } \\
\text { data }\end{array}$ \\
\hline 0.8 & $--^{1}$ & $--^{1}$ & \\
2.3 & $--^{1}$ & $-\mathrm{X}^{1}$ & \\
6.0 & $\mathrm{X}$ & $\mathrm{X}$ & - \\
\hline
\end{tabular}

${ }^{1}$ Dual instrumentation. 
evening of October 11. An electromagnetic current meter $0.85 \mathrm{ft}$ above the bed, an OBS sensor $0.33 \mathrm{ft}$ above the bed, and a pressure transducer at the bed collected reliable data. Burst data were collected on the hour and averaged data were stored on the half-hour throughout the deployment. Discrete water samples were collected daily at the shallow-water monitoring site for the calibration of the OBS sensor outputs. Net sediment resuspension was detected at the shallow-water monitoring site.

\section{November 28-December 3, 1990}

Sediment resuspension monitoring equipment was deployed on November 28, 1990, because a cold front was forecast to pass through the Tampa Bay area on November 29 . The associated high pressure system behind the front was expected to produce strong northerly winds. Some equipment problems at the deepwater monitoring site continued to affect the resuspension monitoring. The inoperative vibrating-wire pressure transducer at the deep-water monitoring site was replaced with a strain-gage transducer for this deployment and provided accurate resolution of wave activity. Two current meters $2.3 \mathrm{ft}$ above the bed malfunctioned for the duration of the deployment, and the east velocity component of the current meter $6.0 \mathrm{ft}$ above the bed failed intermittently. Two OBS sensors at $0.8 \mathrm{ft}$ above the bed and one OBS sensor $2.3 \mathrm{ft}$ above the bed malfunctioned shortly after the beginning of the deployment. The automatic water sampler on the platform functioned erratically after 1300 hours on November 30, 1990. The deep-water monitoring site operational instruments and their respective elevations above the bottom are listed in table 9 .

Light irradiance was measured using three spherical irradiance sensors and two data loggers that

Table 9. Operational deep-water monitoring site instrument elevations above the bed in Old Tampa Bay, November 28December 3, 1990

[X. operational; I. intermittant; -, not operational]

\begin{tabular}{cccc}
\hline $\begin{array}{c}\text { Elevation } \\
\text { (feet) }\end{array}$ & $\begin{array}{c}\text { Velocity } \\
\text { data }\end{array}$ & $\begin{array}{c}\text { Optical } \\
\text { backscatterance } \\
\text { data }\end{array}$ & $\begin{array}{c}\text { Pressure } \\
\text { data }\end{array}$ \\
\hline 0.8 & $\mathrm{X} \mathrm{X}^{1}$ & $--^{1}$ & \\
2.3 & $--{ }^{1}$ & $-\mathrm{X}^{1}$ & \\
6.0 & $\mathrm{I}$ & $\mathrm{X}$ & $\mathrm{X}$ \\
\hline
\end{tabular}

${ }^{1}$ Dual instrumentation. were deployed on November 26. One light sensor was mounted approximately $11 \mathrm{ft}$ above the steel deck, and two sensors were suspended below the water surface from a floating structure at depths of 1.6 and $8.3 \mathrm{ft}$. The floating light sensor structure was inadvertently destroyed by the servicing boat in rough seas on the morning of November 30, 1990. Additional light measurements, using a flat radiance sensor and a quantum radiometer, were performed at the platform each day of the deployment. Net sediment resuspension was detected at the deep-water monitoring site on November 30.

An example of typical data is presented for this deployment. The deep-water monitoring site hourly water depths, wind speed, and wind azimuth are shown in figure 8 , the deep-water site hourly mean north and east water-velocity components are shown in figure 9 , and the concentrations of suspended solids 2.3 and $6.0 \mathrm{ft}$ above the bed are shown in figure 10 . The deep-water site 5-minute light attenuation coefficients for the top $8 \mathrm{ft}$ of the water column are shown in figure 11. Water-quality data for the decp-water site are listed in table 10.

The submersible instrument package was positioned at the shallow-water monitoring site after the deep-water monitoring site instruments were deployed and operationally checked. The shallow-water instrument package was deployed from 1056 hours on November 28, 1990, to 1130 hours on December 2, 1990. Burst data were collected on the hour and averaged data were stored on the half-hour throughout the deployment. An electromagnetic current meter $0.85 \mathrm{ft}$ above the bed, an OBS sensor $0.33 \mathrm{ft}$ above the bed, and a pressure transducer at the bed recorded reliable data. Light measurements were performed at the shallow-water site each day of the deployment using a flat radiance sensor and a quantum radiometer. Discrete water samples were collected at the shallow-water site each day of the instrument deployment for the calibration of the OBS sensor outputs. Net sediment resuspension was detected at the shallow-water monitoring site on November 30 .

Examples of typical data collected at the shallow-water monitoring site are presented for this deployment. The results of the analyses of water samples collected at the shallow-water monitoring site are presented in table 10 . The half-hourly mean water depths, the mean north and east water-velocity components, and the calculated concentrations of suspended solids are shown in figure 12. 

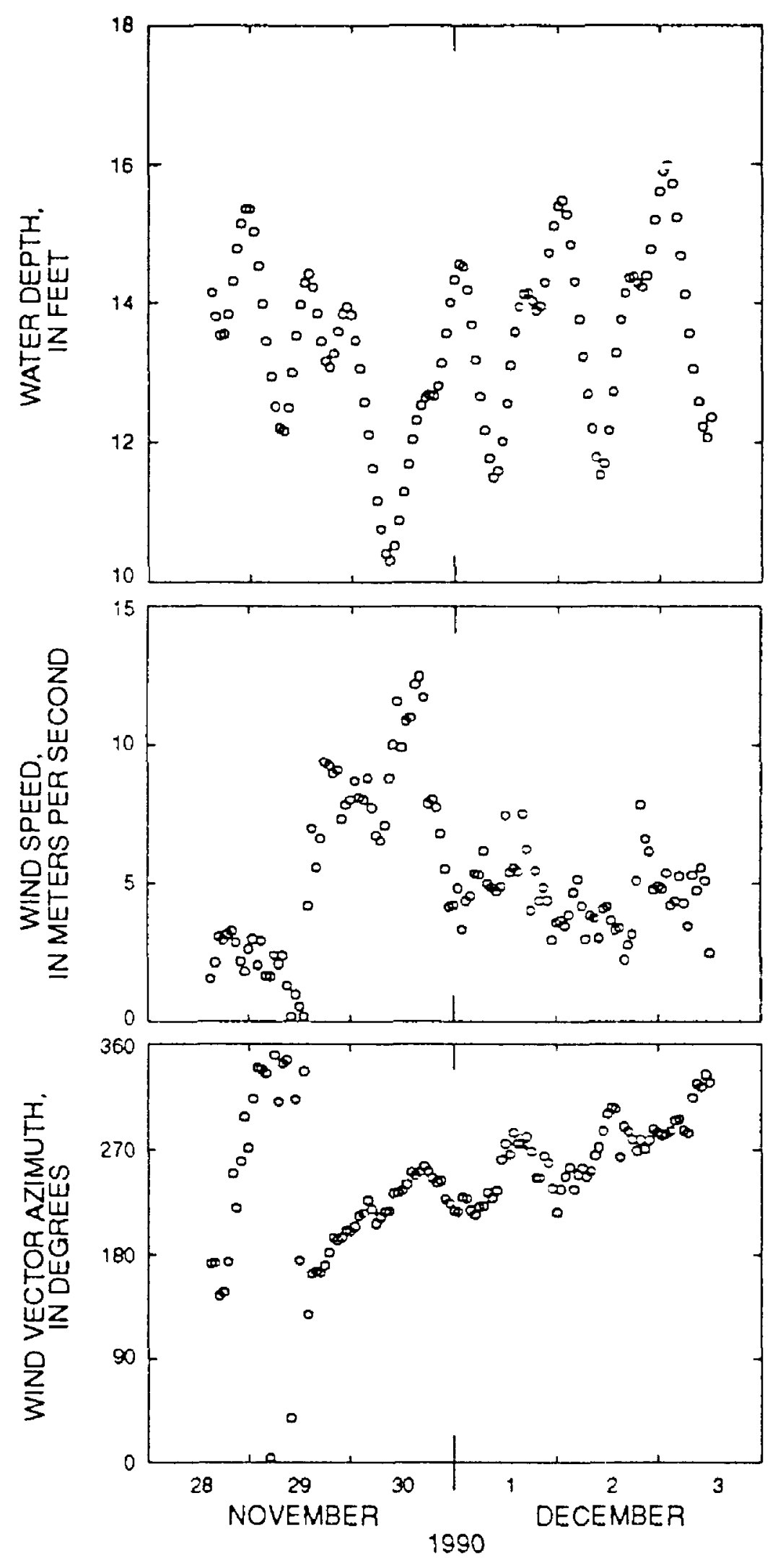

Figure 8. Hourly mean water depth, mean wind speed, and mean wind azimuth, November 28-December 3, 1990, at deep-water monitoring site in Old Tampa Bay.

\section{RESUSPENSION MONITORING ACTIVITIES IN HILLSBOROUGH BAY}

Two reconnaissance instrument deployments were made in Hillsborough Bay in 1990 and four instrument deployinents were made in 1991 (table 11). Information on the large vessels that utilized the ship channel during the instrument deployments in Hillsborough Bay was obtained from the Tampa Port Authority, the Tampa Bay Pilots Association, a local newspaper, and field observations. The vessel information generally included notification of arrival or departure time, dock used, cargo, length, beam (or width), draft (draft reported by the vessel pilot unless noted otherwise), and gross tonnage (equal to the enclosed vessel volume, 1 gross ton $=100 \mathrm{ft}^{3}$ ). Vessel information was not always complete, and some vessels may not have been included. Most vessel wakes detected at the Hillsborough Bay study sites could be matched with a specific vessel, but sometimes this could not be done because the vessel information did not indicate that a vessel was in the Hillsborough Bay channel or more than one vessel could have caused the detected wake. The speed of vessels in the channel during servicing trips was often determined by taking bearings of the vessel from a known position or by traveling in the servicing boat at the same speed as that of the vessel and recording speed and position determined by navigational equipment. Vesscl movement referred to in the tables as inbound in Hillsborough Bay infers a northerly course. Table 11 summarizes the reason for deployments, the sites where data were collected, and the type of data collected.

\section{Monitoring in 1990}

The submersible instrument package used at the Old Tampa Bay shallow-water monitoring site was deployed at Hillsborough Bay deep-water monitoring site B on March 14-15, 1990, and September 6, 1990. This instrument package was designated as Alpha when deployed in Hillsborough Bay.

\section{March 14-15, 1990}

The Alpha instrument package was deployed at Hillsborough Bay deep-water monitoring sitc B and collected data from 1300 hours on March 14, 1990, to 0830 hours on March 15, 1990. An electromagnetic current meter $0.85 \mathrm{ft}$ above the bed, an OBS sensor $0.33 \mathrm{ft}$ above the bed, and a pressure transducer at the bed recorded reliable data. A burst sample was collected and stored at a $1-\mathrm{Hz}$ frequency for 4 minutes on the hour, and the minimum, maximum, mean, and standard deviation of a 1-minute long sample at a 1-Hz frequency were stored on the half-hour. Discrete water samples were collected every hour with a peristaltic pump and tubing 


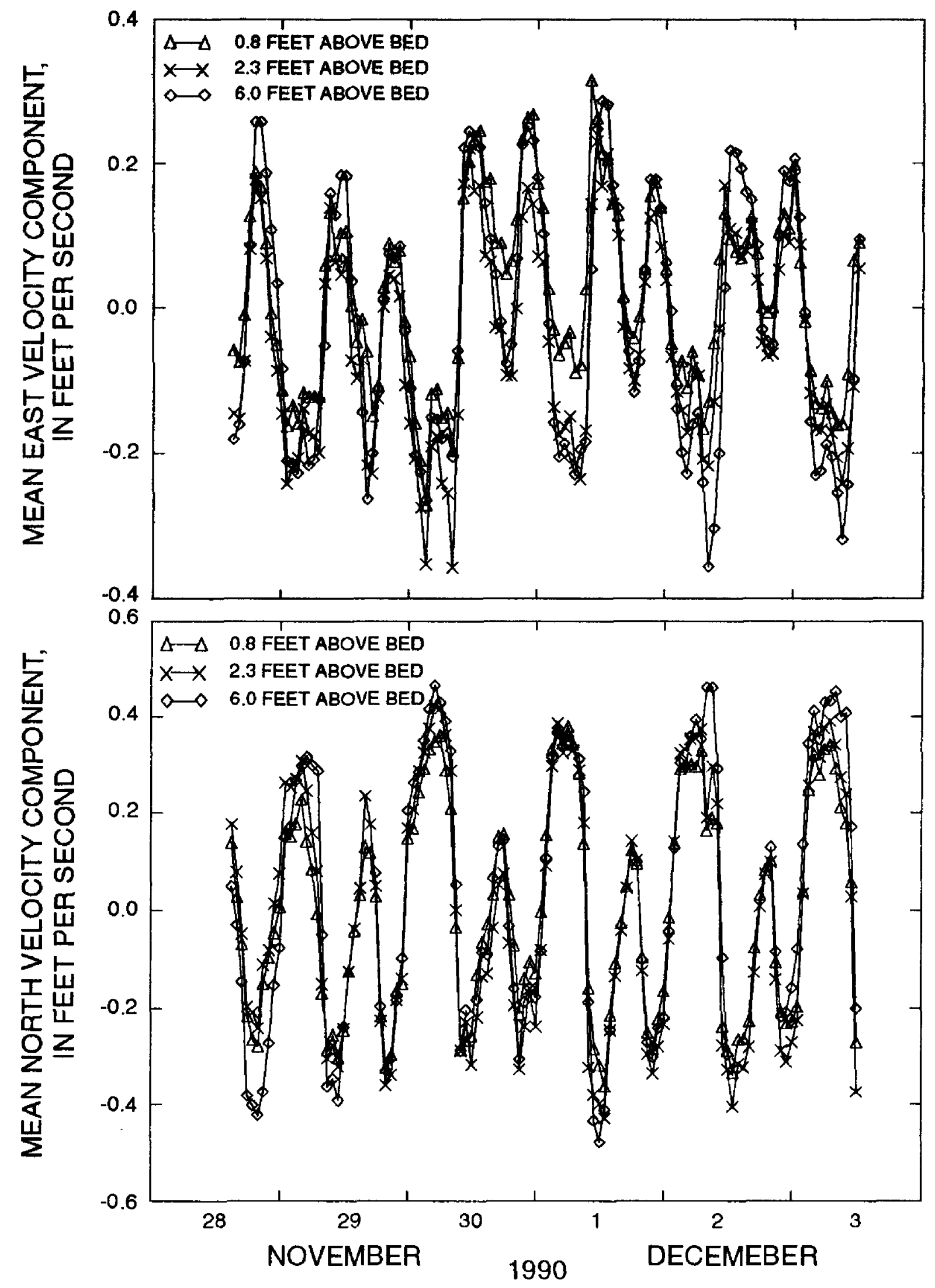

Figure 9. Hourly mean north and east water velocity components, November 28December 3, 1990 at the deep-water monitoring site in Old Tampa Bay.

connected to the instrument stand and at an elevation of $7 \mathrm{ft}$ above the bed with a Kemmerer tube. A vertical profile of velocity and OBS was measured with portable instrumentation on the half-hour. Wind speed, wind direction, estimated wave height, secchi depth, and water depth were recorded every half-hour.

A vessel-generated long wave was recorded at 0200 hours on March 15 (table 12). Water depth, watervelocity components, and concentrations of suspended solids are shown in figure 13. Water depth decreased $1.7 \mathrm{ft}$ and the current speed increased to almost $1.4 \mathrm{ft} / \mathrm{s}$ from 50 to 90 seconds after the start of the data collection. The concentration of suspended solids increased concurrently to a maximum of $790 \mathrm{mg} / \mathrm{L}$ and decreased during the later half of the burst sample. The water sample collected at approximately 0200 hours had a concentration of $132 \mathrm{mg} / \mathrm{L}$, but the exact period of collection (accurate to within seconds) is unknown. 


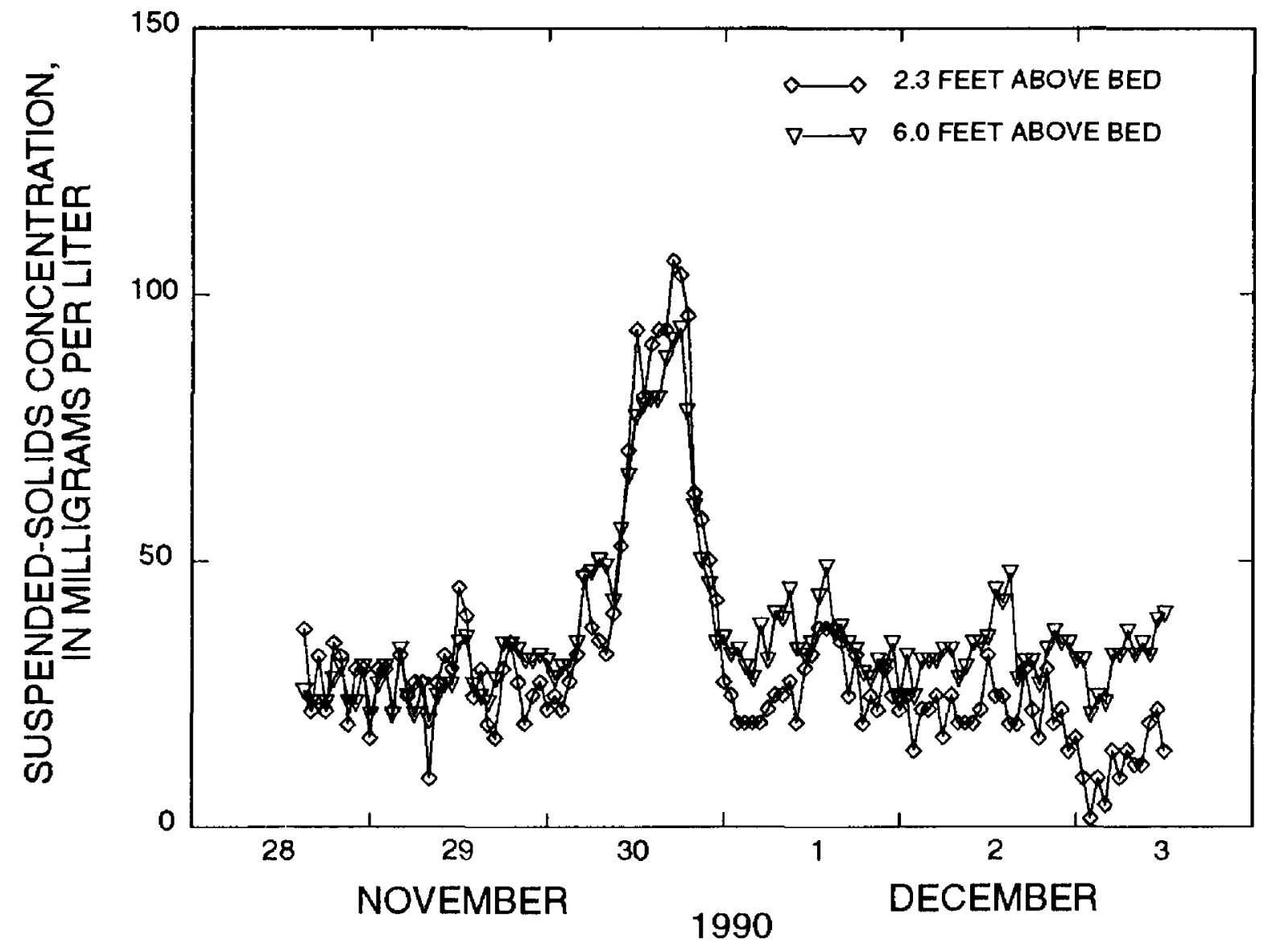

Figure 10. Hourly concentrations of suspended solids at 2.3 and 6.0 feet above the bed, November 28-December 3,1990 at the deep-water monitoring site in Old Tampa Bay.

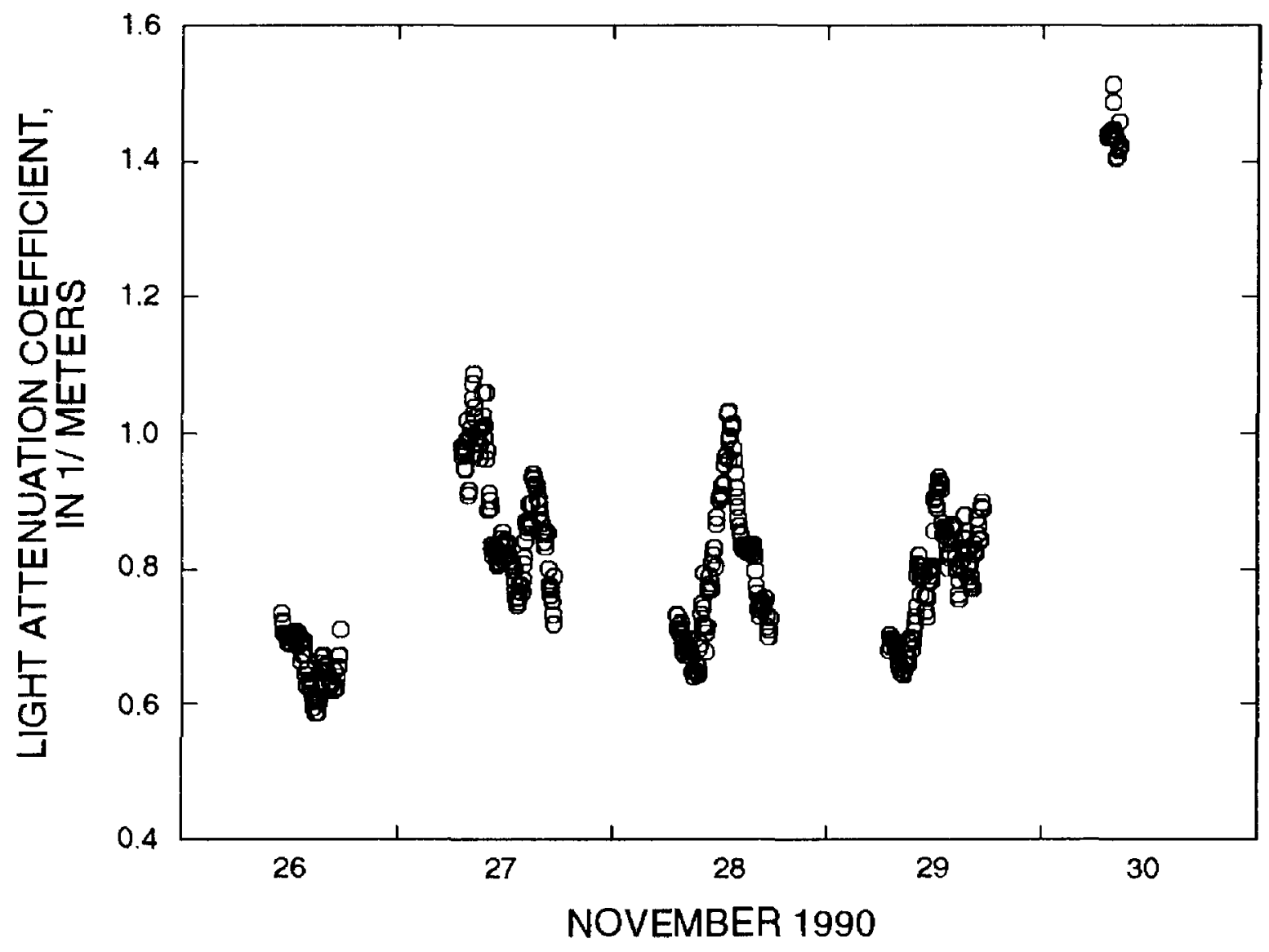

Figure 11. Five-minute light attenuation coefficients, November 26-30, 1990 at the deepwater monitoring site in Old Tampa Bay. 
Table 10. Water-quality data collected at the deep-water and shallow-water monitoring sites in Old Tampa Bay, December 3, 1990

\begin{tabular}{|c|c|c|c|}
\hline \multirow[b]{2}{*}{ Constituent } & \multicolumn{2}{|c|}{ Deep-water site } & \multirow[b]{2}{*}{$\begin{array}{c}\text { Shallow- } \\
\text { water site }\end{array}$} \\
\hline & $\begin{array}{c}\text { Top } 2 \\
\text { meters } \\
\end{array}$ & $\begin{array}{c}\text { Depth- } \\
\text { integrated }\end{array}$ & \\
\hline Chloride (mg/L) & - & 15,000 & 15,000 \\
\hline Chlorophyll $\underline{\mathrm{a}}(\mu \mathrm{g} / \mathrm{L})$ & 7.3 & - & 2.8 \\
\hline Chlornphyll b $(\mu \mathrm{g} / \mathrm{L})$ & .2 & - & $<.1$ \\
\hline Color (Pt-Co) & $<5$ & 一 & $<5$ \\
\hline Dissolved organic carbon ( $\mathrm{mg} / \mathrm{L}$ ) & 1.1 & - & 1.1 \\
\hline $\begin{array}{l}\text { Light attenuation } \\
\text { coefficient (1/meter) } \\
\text { Secchi depth (inches) }\end{array}$ & $37^{1.6}$ & - & $48^{.9}$ \\
\hline Specific conductance $(\mu \mathrm{S} / \mathrm{cm})$ & - & 40,500 & 41,000 \\
\hline Water temperature $\left({ }^{\circ} \mathrm{C}\right)$ & 20.0 & - & 19.5 \\
\hline Total suspended solids (mg/L) & 33 & 34 & 28 \\
\hline Volatile suspended solids (mg/L) & 10 & 10 & 9 \\
\hline Turbidity (NTU) & 2.0 & - & .8 \\
\hline Water depth (meters) & - & 3.6 & 1.7 \\
\hline
\end{tabular}

The concentrations of suspended solids shown in figure 13 were determined with a laboratory calibration of the OBS sensor that is linear and in good agreement with the field data (Schoellhamer, 1992). The long wave was generated by a northbound vessel. The water-surface displacement was estimated for the long-wave component of the pressure transducer data by applying the shallow water wave assumption, which is valid for lowfrequency waves at this site. Surface chop, the higher frequency variations in figure 13 , arrived at monitoring site $B$ after the long wave because a low frequency wave travels faster than a higher frequency wave according to linear wave theory (Dean and Dalrymple, 1984). Tidal currents and waves generated by a southerly breeze did not cause net sediment resuspension.

\section{September 6, 1990}

The Alpha instrument package was deployed at Hillsborough Bay deep-water monitoring site B on September 6, 1990, to monitor vessel-generated long waves. An electromagnetic current meter $0.85 \mathrm{ft}$ above the bed, an OBS sensor $0.33 \mathrm{ft}$ above the bed, and a pressure transducer at the bed recorded and stored data at a $1-\mathrm{Hz}$ frequency from 0930 to 1850 hours, but a communication failure between the data recorder and data storage module allowed only data recorded from 1720 to 1850 hours to be recovered. Water samples occasionally were collected with a peristaltic pump and tubing connected to the instrument stand.
A pressure transducer was deployed at site $D$ from 1016 to 1844 hours on September 6. Data were recorded and stored at a $1-\mathrm{Hz}$ frequency. A temporary water-level gage was read periodically, and the pressure transducer output was calibrated to an arbitrary water-surface elevation. Two large vessels passed through the navigation channel during the instrument deployment (table 12). Vessel speed was estimated using the rate of change of the azimuth angle of the vessel from a known location and the location of the ship channel. Sediment resuspension was not observed at the deep-water monitoring site. Wakes from two oulbound tugboats, one with a barge, were not noticeable at either site.

\section{Monitoring in 1991}

Two additional submersible instrument packages, designated Bravo and Charlie, and consisting of two pairs of a current meter and an OBS sensor and one pressure transducer, were deployed in Hillsborough Bay during 1991. Deployments were made March 11-15, May 28-31, July 22-24, and September 25-27, 1991.

\section{March 11-15, 1991}

Submersible instrument packages Alpla and Bravo were deployed at the Hillsborough Bay shallow-water monitoring site $\mathrm{A}$ and deep-water monitoring site B, respectivcly, on March 11, 1991, to monitor vessel-generated long waves and potential 


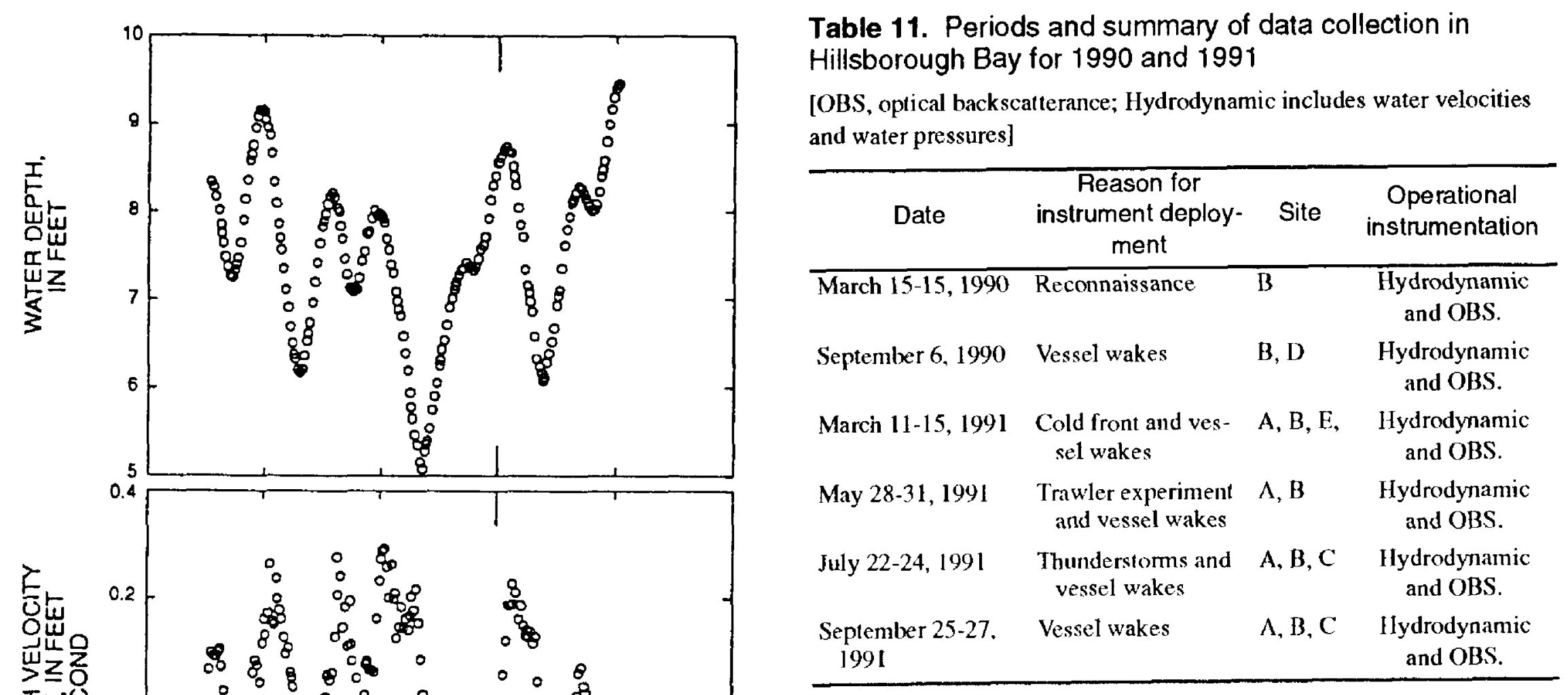

sediment resuspension by an approaching winter frontal system. An electromagnetic current meter $0.96 \mathrm{ft}$ above the bed, an OBS sensor $0.58 \mathrm{ft}$ above the bed, and a pressure transducer at the bed recorded data at shallow-water monitoring site A. The instruments recorded and stored data at a $1-\mathrm{Hz}$ frequency from 0800 to 1800 hours on March 11. These data were used to analyze vessel-generated long waves. A 5-minute burst sample at a frequency of $1 \mathrm{~Hz}$ was recorded and stored on the hour, and the mean, minimum, maximum, and standard deviation of a 1-minute sample recorded at a frequency of $1 \mathrm{~Hz}$ were stored on the half-hour from 1800 hours on March 11 to 0900 hours on March 15. Discrete water samples were collected daily for the calibration of the OBS sensors.

Instrument package Bravo with one pressure transducer and two pairs of an electromagnetic current meter and an OBS sensor were deployed at deep-water monitoring site $B$. The elevations of the sensors above the bed are listed in table 13 . The water-sample collection tubing was inadvertently pulled from the servicing boat and overturned the instrument stand on March 12; therefore, data from the two current meters and the OBS sensor at $1.5 \mathrm{ft}$ were invalid from 1045 hours on March 12 until 1115 hours on March 14 when a diver reset the stand. The elevation of the lower OBS sensor was $0.4 \mathrm{ft}$ above the bed and oriented upward while the stand was overturned, but the pressure transducer was not affected. The instruments recorded and stored data at a $1-\mathrm{Hz}$ frequency from 1000 to 1800 hours on March 11. These data were used to analyze vessel-generated long waves.
Figure 12. Half-hourly mean water depth, north and east water velocity components, and concentrations of suspended solids, November 28-December 3, 1990 at the shallow-water monitoring site in Old Tampa Bay. 
Table 12. Vessel information and wake description for Hillsborough Bay instrumentation deployments in March and September 1990

[ft, feet; ft/s, feet per second, -, no data]

\begin{tabular}{|c|c|c|c|c|c|c|c|c|c|c|}
\hline Date & Time & $\begin{array}{l}\text { Vessel } \\
\text { name }\end{array}$ & Direction & $\begin{array}{l}\text { Length } \\
\text { (feet) }\end{array}$ & $\begin{array}{l}\text { Beam } \\
\text { (feet) }\end{array}$ & $\begin{array}{l}\text { Draft } \\
\text { (feet) }\end{array}$ & $\begin{array}{c}\text { Gross } \\
\text { tonnage }\end{array}$ & $\begin{array}{l}\text { Speed } \\
\text { (knots) }\end{array}$ & Site & Wake description \\
\hline $3 / 15 / 90$ & 0200 & Omi Charger & Itrbound & 660 & 90 & 26 & 17,320 & - & $\mathrm{B}$ & $\begin{array}{l}\text { Long wave } 1.7 \mathrm{ft} \mathrm{high,} \\
1.5 \mathrm{ft} / \mathrm{s} \text { maximum } \\
\text { velocity, concurrent } \\
\text { sediment resuspen- } \\
\text { sion, chop (fig. 13). }\end{array}$ \\
\hline $9 / 06 / 90$ & 1800 & $\begin{array}{l}\text { Pennsylvania } \\
\text { Trader }\end{array}$ & Inbound & 669 & 86 & 35 & 20,046 & 11 & D & $\begin{array}{l}\text { Long wave } 0.45 \mathrm{ft} \\
\text { high, } 0.48 \mathrm{ft} / \mathrm{s} \text { maxi- } \\
\text { mum velocity, chop, } \\
\text { no resuspension. } \\
\text { Long wave } 0.5 \mathrm{ft} \text { high, } \\
\text { chop }\end{array}$ \\
\hline
\end{tabular}

A 3-minute burst sample at a frequency of $1 \mathrm{~Hz}$ was recorded and stored on the hour, and the mean, minimum, maximum, and standard deviation of a 1-minute sample collected at a frequency of $1 \mathrm{~Hz}$ were stored on the half-hour from 1800 hours on March 11 to 0530 hours on March 15. Several water samples were collected during the deployment.

A pressure transducer was deployed at site $\mathbf{E}$ from 1100 to 1750 hours on March 11 to measure vessel waves. Data were recorded and stored at a $1-\mathrm{Hz}$ frequency. The pressure transducer output was calibrated to water-surface elevation (arbitrary datum) with a previous field calibration that was verified in the laboratory.

Rough seas were generated by strong southerly winds associated with a winter cold front on March 13, and the concentration of suspended solids in Hillsborough Bay was affected. Concentrations of suspended solids at shallow-water monitoring site A increased during the passage of the cold front. When the instrument stand was overturned on March 13, concentrations of suspended solids at the deep-water monitoring site were difficult to interpret. The OBS sensor outputs increased at the time of slack tide, indicating that sediment was depositing on the sensor face. Sediment resuspension possibly occurred at the decp-water monitoring site during the morning of March 13.

Four large vessels passed through the navigation channel on March 11 while the instruments were continuously recording (table 14). Vessel speed was estimated using the rate of change of the azimuth angle to the vessel from a known location and the location of the ship channel.

\section{May 28-31, 1991}

Submersible instrument package Alpha was deployed at the Hillsborough Bay shallow-water monitoring site A on May 28, 1991. An electromagnetic current meter $0.96 \mathrm{ft}$ above the bed, an OBS sensor $0.58 \mathrm{ft}$ above the bed, and a pressure transducer at the bed recorded data at the shallow-water monitoring site. A 5-minute burst sample at a frequency of 1

$\mathrm{Hz}$ was recorded and stored on the hour, and the mean, minimum, maximum, and standard deviation of a 1-minute sample recorded at a frequency of $1 \mathrm{~Hz}$ were stored on the half-hour from 1400 hours on May 28 to 0700 hours on May 30 and from 1400 hours on May 30 to 1030 hours on May 31. The instruments recorded and stored data at a $1-\mathrm{Hz}$ frequency from 0700 to 1400 hours on May 30. These data were used to analyze vessel-generated long waves. One of the output channels of the electromagnetic current meter did not respond until 0750 hours on May 30. Discrete water samples were collected daily for the calibration of OBS sensor outputs.

Instrument package Bravo with a pressure transducer and two pairs of an electromagnetic current meter and an OBS sensor were deployed at deep-water monitoring site B. Elevations of the sensors are listed in table 13. The instruments recorded and stored data at a 1- Hz frequency from 0900 to 1200 hours on May 28 during a trawling experiment and from 0900 to 1400 hours on May 30 to monitor vessel-generated 
Table 14. Vessel information and wake description for Hillsborough Bay instrumentation deployments in March [ft, feet; $f t / s$, feet per second, - , no data]

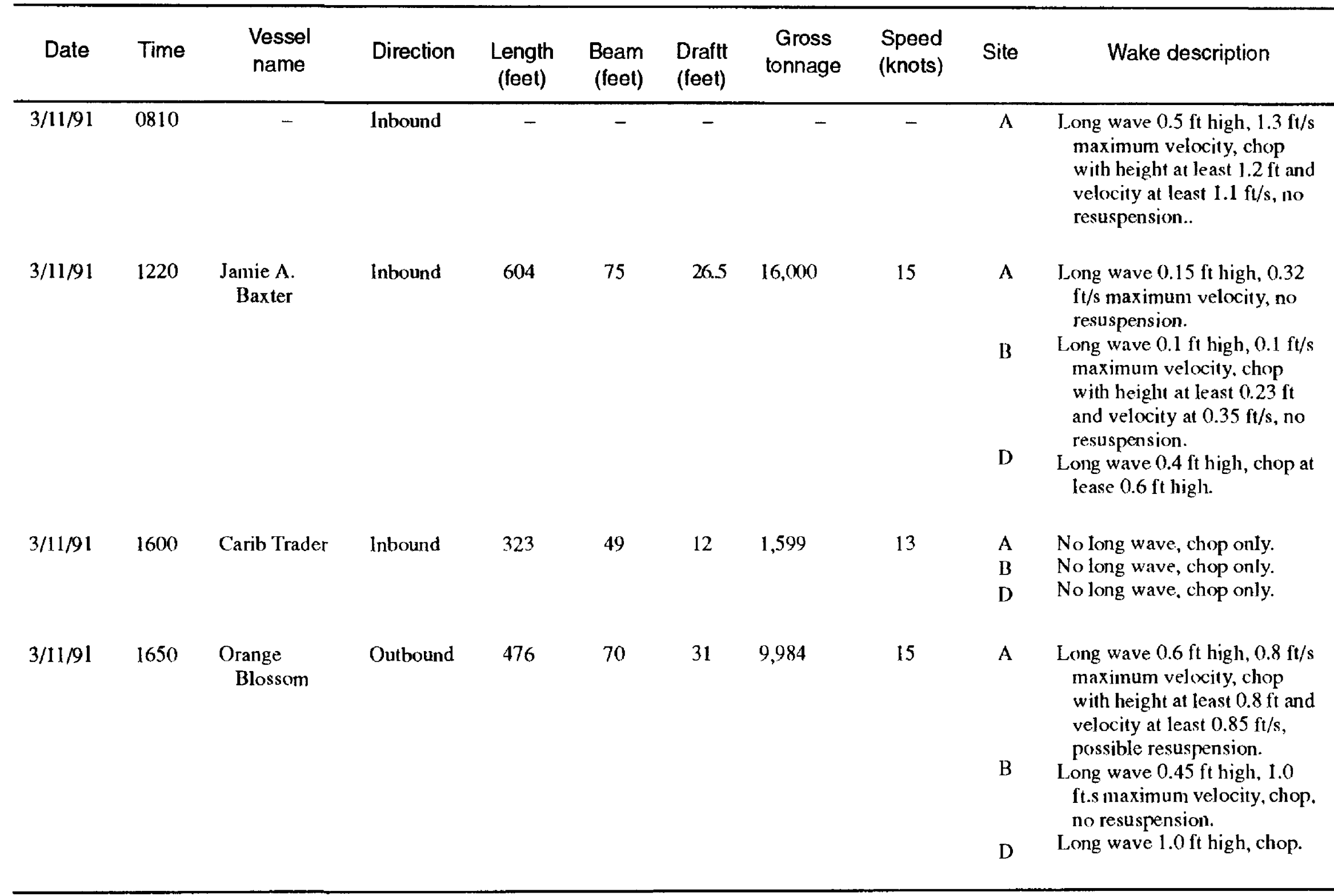

Table 15. Experimental trawls at Hillsborough Bay deepwater monitoring site B, May 28, 1991

\begin{tabular}{cccc}
\hline Pass & Direction & $\begin{array}{c}\text { Time south of } \\
\text { site B }\end{array}$ & $\begin{array}{c}\text { Time surface plume } \\
\text { observed at site B }\end{array}$ \\
\hline 1 & $\begin{array}{c}\text { east to } \\
\text { west }\end{array}$ & 0915 & 0932 \\
2 & $\begin{array}{r}\text { west to } \\
\text { east }\end{array}$ & 0928 & 0936 \\
3 & $\begin{array}{c}\text { east to } \\
\text { west }\end{array}$ & 0942 & 0950 \\
4 & $\begin{array}{r}\text { east to } \\
\text { west }\end{array}$ & 1018 & 1030 \\
5 & $\begin{array}{r}\text { west to } \\
\text { east }\end{array}$ & 1033 & 1046 \\
6 & $\begin{array}{c}\text { east to } \\
\text { west }\end{array}$ & 1046 & 1107 \\
\hline
\end{tabular}

The increase in concentration of suspended solids at 1120 hours was not related to one of the six trawler plumes, but could have been caused by the resuspension of sediments that previously had been suspended by the trawler and then deposited. The resuspension could have been caused by the increased floodtide current speed.

No large vessels passed through the navigation channel during the morning of May 28 when the deep-water monitoring site instruments were recording continuously, but two large vessels passed through the navigation channel on May 30 while the instruments at the shallow-water and deep-water monitoring sites were recording continuously (table 16). Large chop at 0730 hours on May 30 resuspended sediments at shallow-water monitoring site A. 


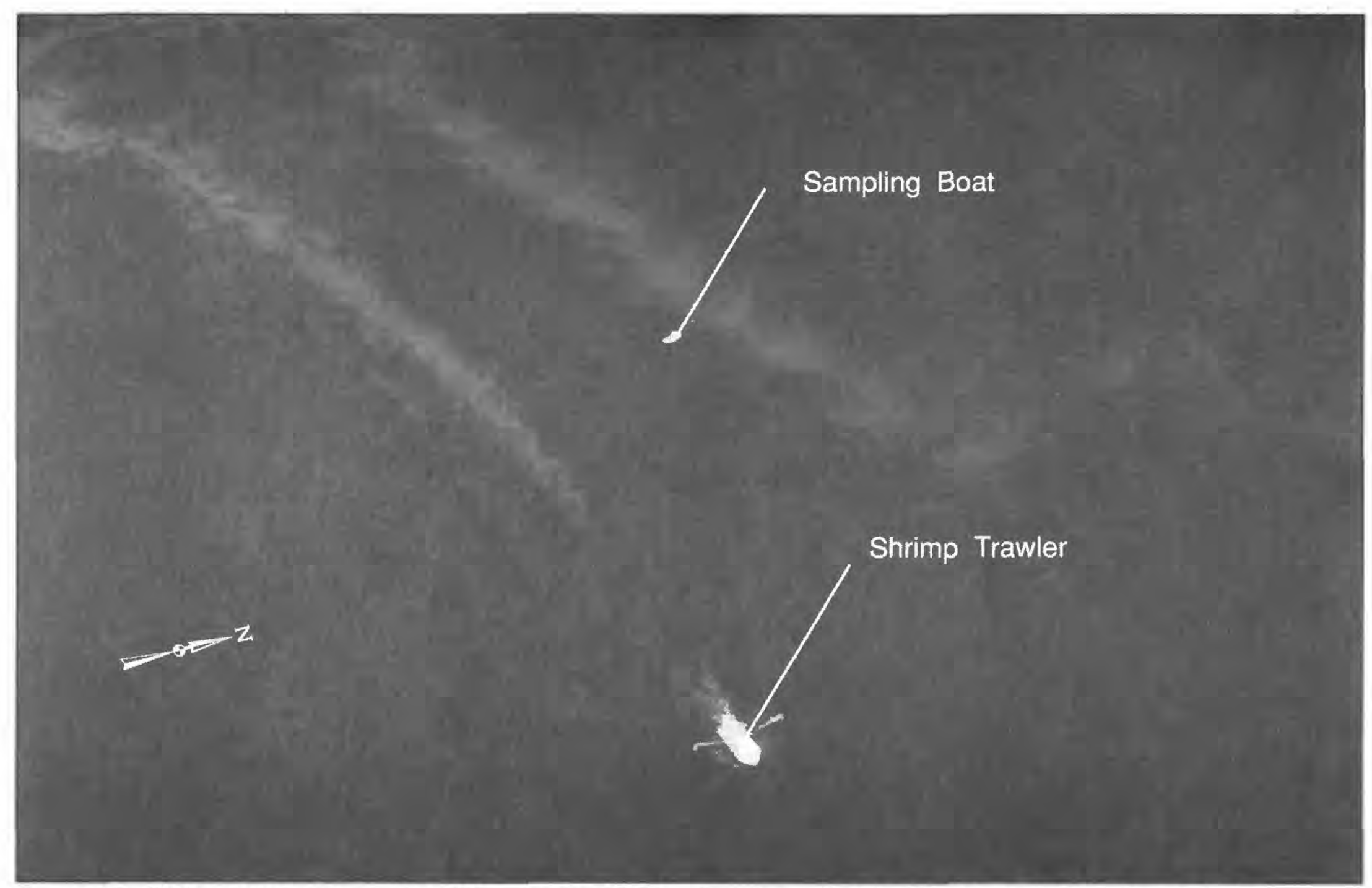

Figure 14. Shrimp trawler conducting fifth experimental trawl and sampling boat anchored at Hillsborough Bay deep-water monitoring site B, 1035 hours, May 28, 1991.

\section{July 22-24, 1991}

Submersible instrument package Alpha was deployed at Hillsborough Bay shallow-water monitoring site A on July 22, 1991, but failed to operate properly. A leak allowed water to enter the package and no data were recorded.

Instrument package Bravo with one pressure transducer and two pairs of an electromagnetic current meter and an OBS sensor were deployed at deep-water monitoring site B. Elevations of the operational sensors are listed in table 17. The instruments recorded data at a $1-\mathrm{Hz}$ frequency from 1200 hours on July 22 to 1200 hours on July 24 . The minimum, maximum, mean, and standard deviation of the instrument outputs were stored every 10 minutes. If the pressure transducer measured a change of water depth greater than $0.2 \mathrm{ft}$ during the 10 -minute period, the entire 10 minute sample was stored on a data storage module. Because of the limits of the data recorder, a 1-minute time window was provided to transfer the data to the storage module, while at the same time, $1-\mathrm{Hz}$ data were recorded but not stored. This data-collection program permitted monitoring of vessel-generated long waves over a 48 -hour period instead of a period of several hours, as was used previously. Discrete water samples were collected during the deployment for the calibration of the OBS sensor outputs.

Instrument package Charlie with two pairs of an electromagnetic current meter and an OBS sensor were deployed at site $C$ approximately 0.3 mi east of deep-water monitoring site B. Elevations of the sensors are listed in table 17. The instruments recorded data at a $1-\mathrm{Hz}$ frequency from 1200 hours on July 22 to 1200 hours on July 24 . The minimum, maximum, mean, and standard deviation of the instrument outputs were stored every 10 minutes. If the pressure transducer measured a change of water depth greater than $0.2 \mathrm{ft}$ during the 10 -minute period, the entire 10minute sample was stored on a data storage module. Because of the limits of the data recorder, a 1-minute time window was provided to transfer the data to the storage module, while at the same time, $1-\mathrm{Hz}$ data were recorded but not stored. This data-collection program permitted monitoring of vessel-generated long waves during a 48-hour period instead of a period of several hours, as was used previously. Water depth was measured to calibrate the pressure transducer, and water samples were not collected at this site because 


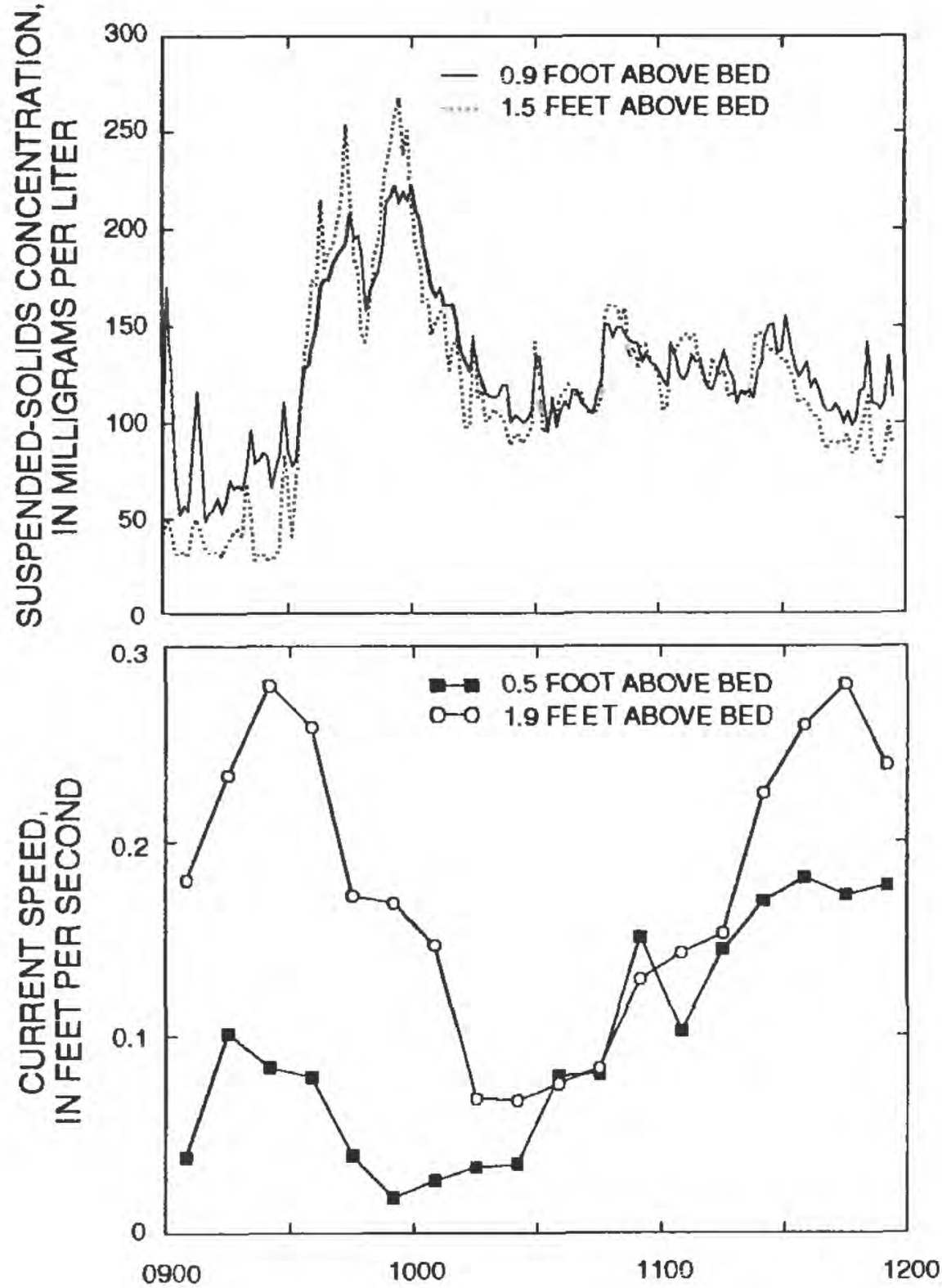

Figure 15. One-minute averages of concentrations of suspended solids and 10-minute averages of the current speed measured at Hillsborough Bay deep-water monitoring site $B, 0900$ to 1200 hours, May 28, 1991. the OBS sensors were used only to qualitatively indicate when bottom sediments resuspended.

Many of the vessels that used the shipping channel during the instrument deployment generated long waves and chop that were observed at monitoring sites $\mathrm{B}$ and C (table 18). Some of the vessel wakes resuspended bottom sediments.

\section{September 25-27, 1991}

Submersible instrument package Alpha was deployed at Hillsborough Bay shallow-water monitoring site A on September 25, 1991. An electromagnetic current meter $0.96 \mathrm{ft}$ above the bed, an OBS sensor $0.58 \mathrm{ft}$ above the bed, and a pressure transducer at the bed recorded data at the shallow-water monitoring site. The output of one of the axes of the current meter was sometimes invalid, and the OBS sensor was fouled during the moming of September 26, late September 26, and September 27. The OBS sensor was cleaned at 1017 hours on September 26. The instruments recorded data at a $1-\mathrm{Hz}$ frequency from 1200 hours on September 25 to 1150 hours on September 27 . The minimum, naximum, mean, and standard deviation of the instrument outputs were stored every 10 minutes. If the pressure transducer detected a change of water depth greater than $0.4 \mathrm{ft}$ during the 10-minute period, the entire 10-minute sample was stored on a data storage module. Because of the limits of the data recorder, a 1-minute time window was provided to transfer the data to the storage module. Meanwhile, $1-\mathrm{Hz}$ data were recorded but not stored.

Table 16. Vessel information and wake description for Hillsborough Bay instrumentation depłoyments in May 1991 [ft, feet; ft/s, feet per second, -, no data]

\begin{tabular}{|c|c|c|c|c|c|c|c|c|c|c|}
\hline $5 / 30 / 91$ & 1300 & Smolnyy & Inbound & 648 & 95 & 33.8 & 25.663 & $\begin{array}{l}10 \text { to } \\
13\end{array}$ & $\begin{array}{l}\mathrm{A} \\
\mathrm{B}\end{array}$ & $\begin{array}{l}\text { No long wave, chop only } \\
\text { Long wave } 0.25 \mathrm{ft} \text { high, } \\
0.3 \mathrm{ft} / \mathrm{s} \text { maximum } \\
\text { velocity, chop, no } \\
\text { resuspension. }\end{array}$ \\
\hline
\end{tabular}


Table 17. Hillsborough Bay deep-water monitoring site B and $C$ instrument elevations above the bed, July 22-24 and September 25-27, 1991

[X, Operational]

\begin{tabular}{cccc}
\hline $\begin{array}{c}\text { Elevation } \\
\text { (feet) }\end{array}$ & $\begin{array}{c}\text { Velocity } \\
\text { data }\end{array}$ & $\begin{array}{c}\text { Optical } \\
\text { backscatterance } \\
\text { data }\end{array}$ & $\begin{array}{c}\text { Pressure } \\
\text { data }\end{array}$ \\
\hline 0.2 & & & $\mathrm{X}$ \\
0.5 & $\mathrm{X}$ & $\mathrm{X}$ & \\
0.9 & & $\mathrm{X}$ & \\
1.5 & & \\
1.9 & $\mathrm{X}$ & \\
\hline
\end{tabular}

Water depth was measured for the calibration of the pressure transducer, and discrete water samples were collected during the deployment to calibrate the OBS sensor outputs.

Instrument package Bravo with two pairs of an electromagnetic current meter and an OBS sensor were deployed at deep-water monitoring site B. Elevations of the sensors are listed in table 17. The upper OBS sensor was fouled on September 27. The instruments collected data at a $1-\mathrm{Hz}$ frequency from 1200 hours on September 25 to 1150 hours on September 27. The minimum, maximum, mean, and standard deviation of the instrument outputs were stored every 10 minutes. If the pressure transducer measured a change of water depth greater than $0.2 \mathrm{ft}$ during the 10-minute period, then the entire 10-minute sample was stored on a data storage module. Because of the limits of the data recorder, a 1-minute time window was provided to transfer the data to the storage module, while at the same time, $1-\mathrm{Hz}$ data were collected but not stored. Water depth was measured for the calibration of the pressure transducer, and discrete water samples were collected for the calibration of the OBS sensor outputs during the deployment.

Instrument package Charlie with one pressure transducer and two pairs of an electromagnetic current meter and an OBS sensor was deployed at site C east of deep-water monitoring site B. Elevations of the operational sensors are listed in table 17. The instruments recorded data at a $1-\mathrm{Hz}$ frequency from 1200 hours on September 25 to 1150 hours on September 27. The mean, minimum, maximum, and standard deviation of the instrument outputs were stored every 10 minutes. If the pressure transducer measured a change of water depth greater than $0.2 \mathrm{ft}$ during the 10 -minute period, the entire 10-minute sample was stored on a data storage module. Because of the limits of the data recorder, a 1-minute time window was provided to transfer the data to the storage module, while at the same time, 1-Hz data were recorded but not stored. Water depth was measured to calibrate the pressure transducer. Water samples were not collected at this site because the OBS sensors were only used to qualitatively indicate when bottom sediments resuspended.

Several vessel-generated long waves were observed at the three sites (table 19) and some of the long waves resuspended bottom sediments. Some of the vessel drafts reported in table 19 are larger than the depth of the shipping channel ( $35 \mathrm{ft}$ ), so available drafts are probably the maximum vessel drafts when fully loaded.

\section{SUMMARY}

This report describes in detail the methods that were used to monitor the resuspension of bottom sediments in Old Tampa Bay and Hillsborough Bay, Florida and summarizes the results of the data collected intermittently from 1988 to 1991 . Electromagnetic current meters, OBS sensors, and a pressure transducer were deployed from a platform at a deepwater monitoring site and a submersible instrument package was deployed at a shallow-water monitoring site in Old Tampa Bay from 1988 until 1990. Example data are presented for one Old Tampa Bay deployment from November 28 to December 3, 1990. Submersible instrument packages were deployed at three monitoring sites in Hillsborough Bay in 1990 and 1991. Example data are presented for two Hillsborough Bay deployments from March 15, 1990 and May 28, 1991. Instruments usually were deployed for 1 to 5 days to monitor the resuspension of bottom sediments as a result of storm systems, and following the passage of large vessels and a shrimp trawler. Bottom sediments were resuspended in Old Tampa Bay and Hillsborough Bay when sufficiently strong storm systems moved through the local area. The resuspension of bottom sediments in Hillsborough Bay also were caused by large vessels using the shipping channels and by trawling activities in the bay. However, the data that were collected should be used with caution when referring to the entire estuary because of the spatial variability encountered in any large natural system. 
Table 18. Vessel information and wake description for Hillsborough Bay instrumentation deployment in July 1991 [ft, feet; ft/s, feet per second; -, no data]

\begin{tabular}{|c|c|c|c|c|c|c|c|c|c|c|}
\hline Date & Time & Vessel name & Direction & $\begin{array}{l}\text { Length } \\
\text { (feet) }\end{array}$ & $\begin{array}{c}\text { Beam } \\
\text { (feet) }\end{array}$ & $\begin{array}{l}\text { Draft } \\
\text { (feet) }\end{array}$ & $\begin{array}{c}\text { Gross } \\
\text { tonnage }\end{array}$ & $\begin{array}{c}\text { Speed } \\
\text { (knots) }\end{array}$ & Site & Wake description \\
\hline $7 / 22 / 91$ & 1240 & New Topaz & Inbound & 623 & 93 & 26.6 & 23,207 & 6 & $\begin{array}{l}\mathrm{B} \\
\mathrm{C}\end{array}$ & $\begin{array}{l}\text { No effect. } \\
\text { No effect. }\end{array}$ \\
\hline $7 / 22 / 91$ & 1300 & Marine Floridian & Outbound & 612 & 80 & 22.6 & 13,401 & 11 & $\begin{array}{l}\mathrm{B} \\
\mathrm{C}\end{array}$ & $\begin{array}{l}\text { Chop only, resuspen- } \\
\text { sion. } \\
\text { Long wave } 0.3 \mathrm{ft} \text { high, } \\
0.3 \mathrm{ft} / \mathrm{s} \text { maximum } \\
\text { velocity, possible } \\
\text { resuspension. }\end{array}$ \\
\hline $7 / 22 / 91$ & 1515 & Condor I & Outbound & 425 & 69 & 17.5 & 7,436 & 7 & $\begin{array}{l}B \\
C\end{array}$ & $\begin{array}{l}\text { No effect. } \\
\text { No effect. }\end{array}$ \\
\hline $7 / 22 / 91$ & 2030 & Philadelphia sun & Outbound & 612 & 90 & 28.3 & 17,491 & -- & B & $\begin{array}{l}\text { No effect. } \\
\text { No effect. }\end{array}$ \\
\hline $7 / \overline{23} / 91$ & 0040 & Pennsylvania & Outbound & 502 & 84 & 22 & 12,591 & $-\infty$ & $\begin{array}{l}B \\
C\end{array}$ & $\begin{array}{l}\text { Chop. } \\
\text { Long wave } 0.3 \text { ft high, } \\
0.2 \text { ft/s maximum } \\
\text { velocity, no resus- } \\
\text { pension. }\end{array}$ \\
\hline $7 / 23 / 91$ & 0200 & Anthenor Express & Inbound & 299 & 46 & 12 & 1,123 & -- & $\begin{array}{l}\mathrm{B} \\
\mathrm{C}\end{array}$ & $\begin{array}{l}\text { No effect. } \\
\text { No effect. }\end{array}$ \\
\hline $7 / 23 / 91$ & 0350 & Neches & Outbound & 661 & 90 & 21.5 & 20,066 & -- & $\begin{array}{l}\mathbf{B} \\
\mathbf{C}\end{array}$ & $\begin{array}{l}\text { Long wave } 0.97 \text { ft high, } \\
0.85 \text { ft/s maximum } \\
\text { velocity, resuspen- } \\
\text { sion, chop. } \\
\text { Long wave } 1.2 \text { ft high, } \\
1.1 \text { ft/s maximum } \\
\text { velocity, resuspen- } \\
\text { sion, chop. }\end{array}$ \\
\hline $7 / 23 / 91$ & 0410 & Batsi Adventurer & Outbound & 443 & 57 & 15 & 4,462 & -- & $\begin{array}{l}\text { B } \\
\text { C }\end{array}$ & $\begin{array}{l}\text { Long wave } 0.34 \text { ft high, } \\
0.1 \text { ft/s maximum } \\
\text { velocity, no resus- } \\
\text { pension. } \\
\text { No effect. }\end{array}$ \\
\hline $7 / 23 / 91$ & 0950 & Rio Vista & Inbound & 557 & 71 & 30.3 & 12,150 & 12 & B & $\begin{array}{l}\text { Long wave } 0.15 \mathrm{ft} \text { high, } \\
0.05 \mathrm{ft} / \mathrm{s} \text { maximum } \\
\text { velocity, no resuspen- } \\
\text { sion. } \\
\text { Long wave } 0.25 \mathrm{ft} \text { high, } \\
0.4 \mathrm{ft} / \mathrm{s} \text { maximum } \\
\text { velocity, no resuspen- } \\
\text { sion. }\end{array}$ \\
\hline $7 / 23 / 91$ & 1310 & Balsa 36 & Outbound & 345 & 54 & 28.1 & 4,337 & -- & $\begin{array}{l}\mathrm{B} \\
\mathrm{C}\end{array}$ & $\begin{array}{l}\text { No effect. } \\
\text { No effect. }\end{array}$ \\
\hline $7 / 23 / 91$ & 1440 & Luigi Lagrange & Inbound & 630 & 85 & 33.1 & 22,077 & -- & C & $\begin{array}{l}\text { Long wave } 0.34 \text { ft high, } \\
0.4 \text { ft/s maximum } \\
\text { velocity, no resuspen- } \\
\text { sion. } \\
\text { Long wave } 0.47 \text { ft high, } \\
0.8 \text { ft/s maximum } \\
\text { velocity, chap, possi- } \\
\text { ble resuspension. }\end{array}$ \\
\hline $7 / 23 / 91$ & 1720 & Hargobind & Inbound & 635 & 91 & 24 & 23,340 & -- & $\begin{array}{l}\mathrm{B} \\
\mathrm{C}\end{array}$ & $\begin{array}{l}\text { Chop, no resuspension } \\
\text { Long wave } 0.24 \text { ft high, } \\
0.3 \text { ft/s maximum } \\
\text { velocity, chop, no } \\
\text { resuspension. }\end{array}$ \\
\hline
\end{tabular}


Table 18. Vessel information and wake description for Hillsborough Bay instrumentation deployment in July $1991-$ Continued [ft, feet; ft/s, feet per second; - , no data]

\begin{tabular}{|c|c|c|c|c|c|c|c|c|c|c|}
\hline Date & Time & Vessel name & Direction & $\begin{array}{l}\text { Length } \\
\text { (feet) }\end{array}$ & $\begin{array}{c}\text { Beam } \\
\text { (feet) }\end{array}$ & $\begin{array}{l}\text { Draft } \\
\text { (feet) }\end{array}$ & $\begin{array}{c}\text { Gross } \\
\text { tonnage }\end{array}$ & $\begin{array}{c}\text { Speed } \\
\text { (knots) }\end{array}$ & Site & Wake description \\
\hline $7 / 23 / 91$ & 2050 & New Topaz & Outbound & 623 & 93 & 34.3 & 23,207 & -- & c & $\begin{array}{l}\text { Long wave } 0.24 \mathrm{ft} \text { high, } \\
0.4 \mathrm{ft} / \mathrm{s} \text { maximum } \\
\text { velocity, no resuspen- } \\
\text { sion. } \\
\text { Long wave } 0.5 \mathrm{ft} \text { high, } \\
1.0 \mathrm{ft} / \mathrm{s} \text { maximum } \\
\text { velocity, resuspen- } \\
\text { sion. }\end{array}$ \\
\hline $7 / 23 / 91$ & 2350 & unknown & Outbound & - & -- & -- & - & -- & C & $\begin{array}{l}\text { Long wave } 0.1 \mathrm{ft} \text { high, } \\
0.1 \mathrm{ft} / \mathrm{s} \text { maximum } \\
\text { velocity, chop, no } \\
\text { resuspension. } \\
\text { Chop, long wave } 0.24 \\
\mathrm{ft} \mathrm{high}, 0.45 \mathrm{ft} / \mathrm{s} \\
\text { maximum velocity, no } \\
\text { resuspension. }\end{array}$ \\
\hline $7 / 24 / 91$ & 0010 & Skaw Trader & Inbound & 479 & 75 & 31 & 10,234 & -- & C & $\begin{array}{l}\text { Long wave } 0.15 \mathrm{ft} \text { high, } \\
0.25 \mathrm{ft} / \mathrm{s} \text { maximum } \\
\text { velocity, chop, no } \\
\text { resuspension. } \\
\text { Long wave } 0.5 \mathrm{ft} \text { high, } \\
0.8 \mathrm{ft} / \mathrm{s} \text { maximum } \\
\text { velocity, chop, possi- } \\
\text { ble resuspension. }\end{array}$ \\
\hline $7 / 24 / 91$ & 0200 & Anthenor Express & Outbound & 299 & 46 & 15 & 1,123 & -- & $\stackrel{B}{C}$ & $\begin{array}{l}\text { No effect. } \\
\text { No effect. }\end{array}$ \\
\hline $7 / 24 / 91$ & 1050 & Condor I & $\begin{array}{l}\text { Inbound } \\
\text { under tow }\end{array}$ & 425 & 69 & 14.5 & 7,436 & 9 & $\begin{array}{l}\mathrm{B} \\
\mathrm{C}\end{array}$ & $\begin{array}{l}\text { No effect. } \\
\text { No effect. }\end{array}$ \\
\hline $7 / 24 / 91$ & 1150 & Stolt Integrity & Inbound & 580 & 89 & 34 & 18,731 & 10 & $\begin{array}{l}\text { B } \\
\text { C }\end{array}$ & $\begin{array}{l}\text { Instruments off. } \\
\text { Long wave } 0.28 \mathrm{ft} \text { high, } \\
0.4 \mathrm{ft} / \mathrm{s} \text { maximum } \\
\text { velocity, no resuspen- } \\
\text { sion. }\end{array}$ \\
\hline
\end{tabular}


Table 19. Vessel information and wake description for Hillsborough Bay intrumentation deployment in September 1991 [ft, feet; ft/s, feet per second; -, no data]

\begin{tabular}{|c|c|c|c|c|c|c|c|c|c|c|}
\hline Date & Iime & Vessel name & Direction & $\begin{array}{l}\text { Length } \\
\text { (feet) }\end{array}$ & $\begin{array}{c}\text { Beam } \\
\text { (feet) }\end{array}$ & $\begin{array}{l}\text { Draft } \\
\text { (feet) }\end{array}$ & $\begin{array}{l}\text { Gross } \\
\text { torrage }\end{array}$ & $\begin{array}{c}\text { Speed } \\
\text { (knots) }\end{array}$ & Site & Wake description \\
\hline $9 / 25 / 91$ & 1330 & unknown & Outbound & -- & -- & -- & -- & -- & $\begin{array}{l}A \\
B \\
C\end{array}$ & $\begin{array}{l}\text { No effect. } \\
\text { No effect. } \\
\text { Chop, no resuspension. }\end{array}$ \\
\hline $9 / 26 / 91$ & 0630 & Khalij Reefer & Inbound & 461 & 65 & 27 & 7,701 & -- & $\begin{array}{l}\text { A } \\
\text { B } \\
\text { C }\end{array}$ & $\begin{array}{l}\text { Chop, possible resus- } \\
\text { pension. } \\
\text { Long wave } 0.55 \text { ft high, } \\
0.5 \mathrm{ft} / \mathrm{s} \text { maximum } \\
\text { velocity, chop, no } \\
\text { resuspension. } \\
\text { Long wave } 0.2 \text { ft high, } \\
0.5 \mathrm{ft} / \mathrm{s} \text { maximum } \\
\text { velocity, chop, no } \\
\text { resuspension. }\end{array}$ \\
\hline $9 / 26 / 91$ & 0900 & Overseas Alice & Outbound & 660 & 90 & 37 & 20,879 & 17 & $\begin{array}{l}\text { A } \\
\text { B } \\
\text { C }\end{array}$ & $\begin{array}{l}\text { Long wave } 1.2 \text { ft high, } \\
1.1 \text { ft/s maximum } \\
\text { velocity, chop, resus- } \\
\text { pension }(40-80 \mathrm{mg} / \mathrm{l}) \text {. } \\
\text { Long wave } 1.4 \mathrm{ft} \text { high, } \\
1.1 \mathrm{ft} / \mathrm{s} \text { maximum } \\
\text { velocity, chop, possi- } \\
\text { ble resuspension. } \\
\text { Long wave } 1.6 \mathrm{ft} \text { high, } \\
1.9 \text { ft/s maximum } \\
\text { velocity, chop, resus- } \\
\text { pension. }\end{array}$ \\
\hline $9 / 26 / 91$ & 0930 & Nelvana & Outbound & 797 & 106 & 46 & 44,340 & 16 & $\begin{array}{l}\text { A } \\
\text { B } \\
\text { C }\end{array}$ & $\begin{array}{l}\text { Long wave with } 0.6 \mathrm{ft} / \mathrm{s} \\
\text { maximum velocity, } \\
\text { chop, no resuspension. } \\
\text { Long wave } 1.1 \text { ft high, } \\
0.8 \mathrm{ft} / \mathrm{s} \text { maximum } \\
\text { velocity, chop, resus- } \\
\text { pension }(45-75 \mathrm{mg} / \mathrm{L}) \text {. } \\
\text { Long wave } 1.4 \mathrm{ft} \mathrm{high,} \\
1.8 \mathrm{ft} / \mathrm{s} \text { maximum } \\
\text { velocity, chop, resus- } \\
\text { pension. }\end{array}$ \\
\hline $9 / 26 / 91$ & 1530 & Alascalbo & Inbound & 712 & 106 & 43 & 36.544 & -- & $\begin{array}{l}\text { A } \\
\text { B } \\
\text { C }\end{array}$ & $\begin{array}{l}\text { No effect. } \\
\text { Long wave } 0.3 \text { ft high, } \\
0.2 \text { ft/s maximum } \\
\text { velocity, chop, no } \\
\text { resuspension. } \\
\text { Long wave } 0.7 \text { ft high, } \\
1.0 \text { ft } / \text { s maximum } \\
\text { velocity, chop, no } \\
\text { resuspension. }\end{array}$ \\
\hline $9 / 26 / 91$ & 1830 & unknown & - & -- & -- & -- & -- & -- & $\begin{array}{l}\text { A } \\
\text { B } \\
\text { C }\end{array}$ & $\begin{array}{l}\text { No effect. } \\
\text { Chop, no resuspension. } \\
\text { Chop, no resuspension. }\end{array}$ \\
\hline $9 / 26 / 91$ & 2100 & unknown & -- & -- & -- & -- & -- & -- & $\begin{array}{l}A \\
B \\
C\end{array}$ & $\begin{array}{l}\text { No effect. } \\
\text { Chop, no resuspension. } \\
\text { Chop, no resuspension. }\end{array}$ \\
\hline $9 / 26 / 91$ & 2215 & unknown & Outbound & -- & -- & -- & -- & -- & $\begin{array}{l}\text { A } \\
\text { B }\end{array}$ & $\begin{array}{l}\text { No effect. } \\
\text { Long wave } 0.2 \text { ft high, } \\
0.1 \text { ft/s maximum } \\
\text { velocity, chop, no } \\
\text { resuspension. } \\
\text { Long wave } 0.4 \text { ft high, } \\
0.5 \text { ft/s maximum } \\
\text { velocity, chop, no } \\
\text { resuspension. }\end{array}$ \\
\hline
\end{tabular}


Table 19. Vessel information and wake description for Hillsborough Bay intrumentation deployment in September 1991-Continued

[ft, feet; ft/s, feet per second; -, no data]

\begin{tabular}{|c|c|c|c|c|c|c|c|c|c|c|}
\hline Date & Iime & Vessel name & Direction & $\begin{array}{l}\text { Length } \\
\text { (feet) }\end{array}$ & $\begin{array}{c}\text { Beam } \\
\text { (feet) }\end{array}$ & $\begin{array}{l}\text { Draft } \\
\text { (feet) }\end{array}$ & $\begin{array}{c}\text { Gross } \\
\text { tonnage }\end{array}$ & $\begin{array}{c}\text { Speed } \\
\text { (knots) }\end{array}$ & Site & Wake description \\
\hline $9 / 27 / 91$ & 0015 & Blue Ridge & Inbound & 659 & 100 & 37 & 21,359 & -- & $\begin{array}{l}\text { A } \\
\mathbf{B}\end{array}$ & $\begin{array}{l}\text { No effect. } \\
\text { Long wave } 0.27 \text { ft high, } \\
0.1 \text { ft/s maximum } \\
\text { velocity, no resuspen- } \\
\text { sion. } \\
\text { Long wave } 0.35 \text { ft high, } \\
0.5 \text { ft/s maximum } \\
\text { velocity, chop, no } \\
\text { resuspension. }\end{array}$ \\
\hline $9 / 27 / 91$ & 0710 & unknown & Inbound & -- & -- & -- & -- & -- & $\begin{array}{l}\text { A } \\
\text { B } \\
\text { C }\end{array}$ & $\begin{array}{l}\text { No effect. } \\
\text { Long wave } 0.15 \text { ft high, } \\
0.1 \text { ft/s maximum } \\
\text { velocity, chop, no } \\
\text { resuspension. } \\
\text { Long wave } 0.55 \text { ft high, } \\
0.9 \text { ft/s maximum } \\
\text { velocity, chop, possi- } \\
\text { ble resuspension. }\end{array}$ \\
\hline $9 / 27 / 91$ & 0940 & Baja California & Inbound & $34 \mathrm{~S}$ & 54 & 22 & 4,010 & 10 & $\begin{array}{l}A \\
B \\
C\end{array}$ & $\begin{array}{l}\text { No effect. } \\
\text { No effect. } \\
\text { No effect. }\end{array}$ \\
\hline
\end{tabular}

\section{SELECTED REFERENCES}

Dean, R.G. and Dalrymple, R.A., 1984, Water wave mechanics for engineers and scientists: Englewood Cliffs, N.J., Prentice-Hall, 353 p.

Downing, J.P., 1983, An optical instrument for monitoring suspended particulates in ocean and laboratory: Proceedings, OCEANS 1983, San Francisco, Calif., August 29-September 1, 1983, p. 199-202.

Downing, J.P., Sternburg, R.W., and Lister, C.R.B., 1981, New instrumentation for the investigation of sediment suspension processes in the shallow marine environment: Marine Geology, v. 42, p. 19-34.

Fishman, M.J., and Friedman, L.C., 1989, Methods for determination of inorganic substances in water and fluvial sediments: U.S. Geological Survey OpenFile Report 85-495, 545p.

Guza, R.T., 1988, Comment on kinematic and dynamic estimates from electromagnetic current meter data, by Aubrey, D.G., and Trowbridge, J.H.: Journal of Geophysical Research, v. 93, no. C2, p. 1337-1343.
Schoellhamer, D.H., 1990, Observations of sediment resuspension in Old Tampa Bay, Florida: Proceedings of the National Conference on Hydraulic Engineering, San Diego, Calif., v. 1, p. 51-56.

1992, Size classification of bed sediment and selection of resuspension monitoring sites in upper Tampa Bay, Florida: U.S. Geological Survey WaterResources Investigations Report 91-4070, 23 p. 1993, Biological interference of optical backscatterance sensors in Tampa Bay, Florida: Marine Geology v. 110, p. 303-313.

1993, Sediment resuspension mechanisms in Old Tampa Bay, Florida: Estuarine, Coastal and Shelf Science.

Spinard, R.W., 1987, Testing of optical properties and development of application procedure for OMP-8 antifoulant on submersible optical surfaces: Corvallis, Ore., Sea Tech, Inc., Reference Technical Report 8701, $44 \mathrm{p}$. 